Pamiętnik Literacki 2015, 4, s. 177-231
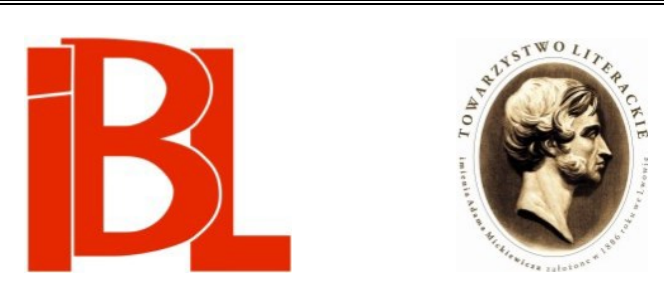

„Nikt z krytyków w tym stopniu, co Pan, nie wniknąl $w$ > >istotny sens $<<$.

Listy Teodora i Eleonory Parnickich do Jacka Łukasiewicza

oprac. Piotr Gorliński-Kucik 


\title{
"NIKT Z KRYTYKÓW W TYM STOPNIU, CO PAN, NIE WNIKNĄE W "ISTOTNY SENS" " LISTY TEODORA I ELEONORY PARNICKICH DO JACKA ŁUKASIEWICZA
}

\author{
Opracował \\ PIOTR GORLIŃSKI-KUCIK Uniwersytet Śląski, Katowice
}

W roku 1958, w lutowym numerze „Więzi”, ukazał się szkic Jacka Łukasiewicza Republika mieszańców ${ }^{1}$. Przeczytał go Teodor Parnicki (czytał bowiem większość tego, co pisała o nim prasa) i w pierwszym $z$ listów tak okazywał swoje zadowolenie: „亡̇ywię głębokie przekonanie, że nikt z krytyków w typ stopniu, co Pan, nie wniknął W "istotny sens" mojej - że się tak wyrażę - "wędrówki pisarskiej"..." (list 1). Później autor Srebrnych orłów jeszcze nieraz sugerował, iż on i Łukasiewicz podobnie „współ-czują, podobnie współodczuwają literaturę.

Adresatem listów jest Jacek Petelenz-Łukasiewicz (publikujący jako Jacek Łukasiewicz), krytyk i poeta, urodzony w 1934 roku we Lwowie, od roku 1951 związany z Wrocławiem. W ciagu lat drukował swoje teksty we „Wrocławskim Tygodniku Katolickim”, „Dziś i Jutro”, „Tygodniku Powszechnym”, „Więzi” (cykl Ćwiczenia miesięczne), „Współczesności”, „Twórczości” i w „Odrze”. Jest członkiem Stowarzyszenia Pisarzy Polskich (od r. 1989) oraz Polskiego Pen Clubu, profesorem Uniwersytetu Wrocławskiego, autorem prac literaturoznawczych i tomików poezji.

Jego szkice krytyczne ukazywały się w prasie, a potem w książkach, m.in. w zbiorach: Zagłoba $w$ piekle (Kraków 1965) i Republika mieszańców (Wrocław 1974), wspomnianych w listach. Studia Łukasiewicza nad poezją zaowocowały np. monografiami: Mieczysława Jastruna spotkania w czasie (Warszawa 1982), Poezja Zbigniewa Herberta (Warszawa 1995), Mickiewicz (Wrocław 1996). Szkice o Parnickim przyniosły wiele cennych konstruktów i strategii lektury, co z kolei w znamienny sposób określiło recepcję tych powieści i oddziałuje dziś na młodszych badaczy.

Parnicki zastrzegał, iż nie chce podpowiadać krytykowi, nic dorzucać do recepcji, argumentując, że literatura powinna obronić się sama. Ale zasadę tę, oczywiście, nieraz łamał. Treść prezentowanych tu listów skupia się przede wszystkim wokół pisarstwa Parnickiego - komentuje on własne utwory, wspomina o swojej biografii i zwraca uwagę na istotniejsze recenzje ukazujące się w prasie.

Pisarz i literaturoznawca wymieniali ze sobą książki, przy czym Parnicki wysyłał Łukasiewiczowi głównie swoje teksty. Później, gdy autor Twarzy księżyca planował przyjazd do Polski na stałe, to właśnie adresat listów organizował jego bi- 
bliotekę, kupował mu ksiażki, doradzał przy ich wyborze. Stąd nieustanne prośby kierowane czy to z Meksyku, czy już z Warszawy.

Inne problemy (egzystencjalne, zdrowotne, nawet towarzyskie) zajmuja w tym zbiorze miejsce marginalne. Dopiero pod koniec życia prozaika proporcja ta ulega zmianie. Opowieść o słabnących oczach i trudności pisania jest przejmująca - Parnicki pracował nie widząc tego, co zapisuje, pisał bardziej pamięcią niż wzrokiem. Zmarł, pozostawiając niedokończone zdanie Ostatniej powieści.

Kontakt listowny między Parnickim a Łukasiewiczem trwał, z różną intensywnością, prawie 29 lat (1959-1988), aż do śmierci autora. W latach siedemdziesiątych obserwujemy jedynie wymianę okolicznościowych kartek pocztowych z życzeniami. Jednak już w następnej dekadzie komunikacja ponownie przybrała na sile, ale wtedy kontakt był utrzymywany nie tylko za pośrednictwem listów, ale i wizyt Łukasiewicza w Warszawie oraz rozmów telefonicznych. Ostatnie listy czytać można równolegle z Dziennikami z lat osiemdziesiatych ${ }^{2}$ (co w pewnej mierze proponuję, prezentując odnośne fragmenty z Dzienników w przypisach).

Parnicki tworzył bardzo dużo. Ponad 30 powieści oraz liczne wypowiedzi prasowe (w okresie międzywojennym i po powrocie do kraju) stanowią dopełnienie listów. Nie da się już dziś jednoznacznie określić, ile i do kogo Parnicki pisał. Należy pogodzić się z myślą, że niektóre zbiory korespondencji nieodwołalnie przepadły. Edycje listów mogą być materiałem do przyszłej biografii autora Srebrnych orłów, odsłaniają także, fragment po fragmencie, liste jego lektur (odpowiedzi na pytanie: „,co czytał Parnicki?”, udzielają w dużym stopniu Dzienniki z lat osiemdziesiatych). Poznanie korespondencji pisarza jest też o tyle ważne, że przecież wiele $z$ jego powieści opiera się na wzorze powieści epistolarnych. Może w efekcie dałoby się połączyć doświadczenia płynące $z$ odczytania listów tworzonych przez powieściowe postaci (a tak naprawdę przez „Narratora głównego”3) z doznaniami związanymi $z$ lekturą listów Parnickiego do bliższych i dalszych znajomych. Jest on przecież jednym z tych prozaików, u których życie (gr. bios) i pisanie (grec. grāphō, 'piszę') splatają się ze sobą nierozerwalnie.

Ciekawe wydaje się zakończenie korespondencji. Ostatnia kartka od Parnickiego pochodzi z marca 1988 i jest podziękowaniem za życzenia urodzinowe. Jej autor zmarł w grudniu, a w kwietniu 1989 do Łukasiewiczów nadszedł list od Eleonory Parnickiej. Tak jak przez lata zajmowała się przepisywaniem powieści męża z manuskryptów, tak i tutaj - ostatnie dwa listy (nie licząc trzech kartek pocztowych) napisała, na maszynie, właśnie Parnicka. I tak jak ostatnią notkę w Dziennikach z lat osiemdziesiatych skreśliła właśnie ona, tak i tutaj: kończy korespondencję, niejako w imieniu swojego męża.

Listy Teodora Parnickiego do Jacka Łukasiewicza tworzą specyficzną narrację, będąca dokumentem życia, pisania i czytania, a także kroniką przyjaźni dwóch ludzi pióra. Prozaik i krytyk zaprzyjaźnili się ze sobą właśnie poprzez literaturę. Spotkali się dopiero w roku 1963 (w trakcie pierwszej po wojnie wizyty Parnickiego

2 T. Parni cki, Dzienniki z lat osiemdziesiatych. Notatkio własnej pracy literackiej. Wstęp Z. Li c hniak. Słowo o autorze dzienników, oprac. T. Marki ew ka. Kraków 2008.

3 Konstrukt ten po raz pierwszy uformował J. Łu ka s i e w i c z w szkicu „Gliniane dzbany” (w: Republika mieszańców. Wrocław 1974). 
w Polsce), wtedy Łukasiewicz „ze "słowa" też się w "ciało" przeobraził”. Życie i literatura zdają się należeć tu do jednego porządku; w przypadku Parnickiego nie można tych sfer oddzielić.

Do listów dodaje jeszcze uzupełnienie. Są to dedykacje na książkach, które Parnicki wręczał Łukasiewiczowi lub wysyłał pocztą. Te barwne zapisy noszą w sobie wyraźne ślady serdeczności. Wydaje się, że stanowią istotny suplement prezentowanego tu zbioru.

Na ten zbiór, pochodzący z lat 1959-1995, składają się 64 jednostki pisane przez Parnickiego, 5 przez Eleonorę Parnicką oraz 12 dedykacji na książkach. Zachowało się 30 kopert: 9 nadanych w Meksyku i 21 z Polski. Okolicznościowe kartki pocztowe wysyłał Parnicki z reguły w adresowanych kopertach. Listy Łukasiewicza pisane do Meksyku zostały prawdopodobnie przez Parnickiego spalone w okresie jego przeprowadzki, te zaś kierowane do Warszawy znajdują się najpewniej w archiwum pisarza.

Niektóre $z$ kartek pocztowych nie noszą dat nadania (i nie mają stempla pocztowego, gdyż były wysyłane w kopertach). Z jednym wyjątkiem (o którym jest mowa na końcu zbioru) - powiodło się bowiem ustalenie przybliżonej daty napisania na podstawie kontekstu (jeśli Parnicki składał życzenia na rok 1961, kartka musiała powstać w grudniu 1960).

Częste u Parnickiego podkreślenia zaznaczono drukiem rozstrzelonym, podkreślenia podwójne dodatkowo kursywą. Liczne dopiski Parnickiego na marginesach wzięto w klamry \{ \}. Skróty zostały w większości przypadków rozwinięte w nawiasach kwadratowych [ ].

Pisarz wykorzystywał każdą wolną przestrzeń: gdy zabrakło miejsca, przenosił się na marginesy kolejnych kart. Wszystkie te przeniesienia skrupulatnie zaznaczał gwiazdkami, odsyłaczami, niekiedy innym kolorem atramentu. Najprawdopodobniej po skończeniu listu czytał go i na czerwono nanosił poprawki oraz dodawał ostatnie słowa. Zmianę barwy na czerwoną, jak też na inne, zasygnalizowano czcionką pogrubioną, w przypisach zaś sprecyzowano, jakiego koloru w danym miejscu użył autor.

W prezentowanej tu korespondencji utrzymano układ nagłówków oraz zakończeń listów. Zachowano także pisownię dużych liter stosowana przez Parnickiego m.in. ze względów grzecznościowych. Ortografia oraz interpunkcja zostały zmodernizowane według obecnie obowiązujących zasad (z jednym wyjątkiem - pozostawiono liczne pauzy, także po przecinku).

Za udostępnienie zbioru i szereg cennych uwag dziękuję Panu prof. Jackowi Łukasiewic z ow i. Wielu rad i wskazówek, za które pragnę podziękować, udzielili mi Pan prof. Krzys z t of Un iłowski oraz Pan dr Tomasz Markiewka.

Serdecznie dziękuje Pani Ele on orze Parnickiej za zgodę na publikację korespondencji.

\section{Listy Teodora Parnickiego do Jacka Łukasiewicza}

Wielce Szanowny i Drogi Panie,

P. Andrzej Piotrowski ${ }^{1}$ powiadomił mnie, że Pan dla „Pallotinum” pisze obszerną (bodajże czteroarkuszową) pracę krytyczną ${ }^{2}$, poświęconą moim powieściom historycznym. Cieszę się z tego ogromnie, że to właśnie Pan ją pisze, - od czasu bowiem przeczytania Pańskiej Republiki mieszańców - oraz przez cały czas porównywania tego eseju $z$ innymi (wcale licznymi) omówieniami moich książek, - żywię głębokie przekonanie, że nikt $\mathrm{z}$ krytyków w tym stopniu, co Pan, nie wniknął w ,istotny sens” mojej - że się tak wyrażę - „wędrówki pisarskiej”...

Nie jest dla mnie jasne, czy to - co teraz Pan o moich książkach pisze - ukaże się w piśmie periodycznym, czy też jako osobna broszura, ba, książka objętości moich Opowiadañ ${ }^{3} \ldots$ 
W tym drugim przypadku miałbym do Pana prośbę, i to dwoistą: 1) czy mógłby Pan zaraz po ukazaniu się tej pracy przysłać mi 5 (pięć) egzemplarzy jej pocztą polecona lotnicza?

2) Czy mógłbym na ręce Pana (względnie do administracji „Pallotinum”) skierować listę zawierającą adresy jakichś 50-60 osób w Polsce i poza Polską, z tym by każda $z$ tych osób - przeze mnie wskazanych w liście - dostała „gratis” po 1 egzemplarzu tej Pańskiej pracy pocztą wprawdzie już n i e lotniczą, ale też p o le c o ną?

Rzecz jasna, - wyrażenie "gratis” używam w tym sensie, iż żadna z owych osób, przeze mnie wskazanych, za owo studium Pańskie nie zapłaci, - bo opłace je wszystkie ja, jak również i te 5 egzemplarzy, które proszę pocztą lotnic zą wysłać do m ni e sa me go. Innymi słowy: będę prosił czy Pana, czy administracje „Pallotinum" o rachunek zawierający łącznie koszta i zakupu przeze mnie tych 55-65 egzemplarzy, i ich przesyłki przez administracje „Pallotinum” pod adresami, jakie wskażę. Rachunek ten zostanie na moje zlecenie uregulowany w złotych w Polsce z konta, jakie mam u wydawców moich książek.

In na sprawa: P. Andrzej Piotrowski podał mi Pana adres głównie z myślą, że może będę chciał sam Panu udzielić jakichś dodatkowych informacji dla tego nowego Pana studium o moich książkach. Otóż w zasadzie nie chcę udzielić ża d ny c h, i myślę, że w tym mi Pan przyklaśnie.

Dzieło - uważam - musi do krytyka przemawiać s a mo od siebie i wszelki dodatkowy komentarz autorski jest, w moim przekonaniu, czymś w rodzaju „votum” nieufności dla dociekliwości i wnikliwości krytyka... Ogromnym jestem entuzjastą Jamesa Joyce'a, a szczególnie Ulyssesa ${ }^{4}$, - tym niemniej mało co kiedy wydało mi się równie śmieszne i małostkowe - że nie powiem „niesmaczne” - jak to, że kilkusetstronicową monografię o twórczości Joyce'a w istocie dociekliwy i wnikliwy skądinąd krytyk, Stuart Gilb ert, poprzedza w Stowie wstępnym zapewnieniem, że cały tekst tej monografii ${ }^{5}$ został z Joyce'em uzgodniony, ba, uzyskał \{aprobatę Joyce'a! Tym niemniej przecież - wbrew swej, wyszczególnionej wyżej, zasadzie, - chciałbym Panu, właśnie i tylko Panu! zrobić - że się tak wyrażę skromny „prezent”, którego, zresztą, może Pan wcale nie potrzebuje, bo albo Pan sam zgadł już to, co chcę Panu powiedzieć, - albo gdy Panu powiem, właśnie to uzna pan za mało istotne. Vide CD. na marginesie str. $2^{6}$ / CD. $\mathbf{z}$ margine s u str. 3. ${ }^{7}$ Może to i jest "mało istotne” obiektywnie, - ale że w Polsce podobno roi się dziś od świetnych znawców literatury rosyjskiej, - ciekawi mnie, wręcz bawi śledzić, czy ktoś kiedyś z moich krytyków rozszyfruje pochodzenie motywu „sceptru srebrnego sławy” w „Księdze” ostatniej Części I Stowa i ciała ${ }^{8}$ (Vide CD. na marginesie str. 1. $)^{9}$ / CD. z margines u str. 2:10 - Zreszta „podrzuciłem” tamże „klucz”, pozwalający, a przynajmniej ułatwiający rozszyfrować ten motyw, - mianowicie w zwrocie „że powtórzę za jakimś wschodnim poetą" it d., it d.... Otóż motyw ten przejęty jest $\mathrm{z}$ wiersza W. B ri u s o w a ${ }^{11}$ Słowo, w którym (co w polskiej parafrazie

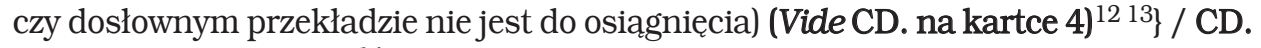
z marginesu str. $1^{14}$ każde słowo zaczyna się na „S”, - mianowicie: „Слово событий скрийжаль, ск и п р с еребяный созданой славы (więc właśnie: sceptr srebrny sławy), светлого солнца (u mnie: Ahura-Mazdy) союзник, святая свирель с еред и голасов (u mnie Frawaszów), сверстник седой с ат аны (u mnie: Arymana), стены судьбы стережет..." itd., itd.... 
A w końcu (vide parafrazę w tejże księdze St[owa] i c[iała): „...слово - стали, секиры, стрелы, сумрачной смерти - страшней..."15

- \{Na tym kończę - raz jeszcze proszę przyjąć ode mnie wyrazy podziwu i uznania za dociekliwość i wnikliwość, ujawnione w Republice mieszańców-j̇yczę Panu dalszych triumfów tejże dociekliwości i wnikliwości w nowej pracy, - dłoń Pańską ściskam serdecznie, - Teodor Parnicki ${ }^{16}$ \{PS. - Adres mój na odwrocie koperty. $\}^{17}$

List na czterech kartach cienkiego, niebieskiego papieru lotniczego, zapisanych jednostronnie granatowym atramentem i czerwonym długopisem. W lewym górnym rogu s. 2-4 pojawia się numeracja (cyframi arabskimi).

1 Andrzej Czcibor-Piotrowski (1931-2014) - poeta i tłumacz. Ukończył slawistykę na Uniwersytecie Warszawskim, związany z tygodnikiem „Dziś i Jutro”, kierownik redakcji literackiej Instytutu Wydawniczego PAX, od roku 1956 współpracujący z „Kierunkami”, potem z „Życiem i Myślą" oraz z „Wrocławskim Tygodnikiem Katolików”, laureat Nagrody Młodych im. Włodzimierza Pietrzaka (1984). Autor wierszy Nadzieja („Życie i Myśl” 1959, nr 56) i Podróże wewnątrz (jw., 1960, nr 1/2) dedykowanych Parnickiemu.

Artykuł miał się znaleźć w tomie zbiorowym, który ostatecznie się nie ukazał.

T. Parnicki, Opowiadania. Warszawa 1958. Wydanie zawiera 120 stronic.

J. J oy c e, Ulysses. Paris 1922. Pierwsze wydanie polskie: Ulisses. Przeł. M. Sło mczyński. Warszawa 1969.

5 S. Gilbert, James Joyce’s „Ulysses”. A Study. London 1930. Wydania późniejsze: 1952, 1963. Stuart Gilb ert (1883-1969) - angielski literaturoznawca i tłumacz. Brał udział w tłumaczeniu Ulissesa na francuski, wydał też korespondencje Joyce’a, z którym łączyła go przyjaźń. Kolorem czerwonym.

Kolorem czerwonym.

T. Parnicki, Stowo i ciało. Powieść z lat 201-203. Warszawa 1959.

Kolorem czerwonym.

Kolorem czerwonym.

Walery Brius ow (1873-1924) - rosyjski poeta, uważany za symbolistę, autor esejów i prozy, tłumacz. Odwołania do jego twórczości często pojawiają się w powieściach Parnickiego.

12 Kolorem czerwonym.

13 Fragment ten ciagnie się od marginesu karty trzeciej, przez margines karty drugiej, aż do marginesu karty pierwszej, by znaleźć swe zakończenie na ostatniej, czwartej karcie listu, niejako w całości poświęconej temu dopiskowi.

Kolorem czerwonym.

15 Fragmenty listu można przetłumaczyć tak: „Słowo - wydarzeń zapis jak srebrne berło tworzonej sławy (więc właśnie: sceptr srebrny sławy), jasnego słońca (u mnie: Ahura-Mazdy) sprzymierzeniec, święty flet pośród głosów (u mnie Frawaszów), rówieśnik szarego szatana (u mnie: Arymana), pilnuje ściany losu...”, ,....słowo - stal, topory, strzały, mrocznej śmierci - strasznej...” Zob. też P a rnicki, Słowo i ciało, s. 243: „Tobie winszuję, o słowo moje - sceptrze sławy srebrnej, jak nazwał był ciebie jakiś wschodni poeta: słońca świetlistego sprzymierzeńcze! Flecie święty Frawaszów sześcioskrzydłych! rówieśniku sędziwy Arymana! Przypadku towarzysz ślepy - tyś straszliwsze niż topór, niż strzała, niż sama śmierć posępna - o słowo! moje słowo! słowo mieszańca, bękarta bełkot żałosny zabawnego książątka barbarzyńskiego!” Zob. też W. Ja. B ri u s o w, Sobranije soczinienij w siemi tomach. T. 3. Moskwa 1974, s. 507.

Kolorem czerwonym.

17 Dopisek u góry s. 1 kolorem czerwonym. 
[grudzień 1959]

Przesyłam Panu i Wszystkim osobom, bliskim Panu, - wiele bardzo Serdecznych Życzeń na „Gwiazdkę” i Rok 1960, - przede wszystkim zaś życzenia dla Pana dalszego świetnego rozwoju na drodze twórczej \{W moim przeświadczeniu praca krytyka literackiego jest forma autonomiczna (jak liryka, dramaturgia czy powieściopisarstwo) twórczości - najniewątpliwiej twórczości! - i artystycznej, i myślowej zarazem! T. P. ${ }^{1}$ subtelnego krytyka i wnikliwego myśliciela.

\section{Dłoń Pańską mocno ściskam}

Teodor Parnicki

México D. F. ${ }^{2}$

Składana kartka świąteczna. Na s. 1 widnieje grafika przedstawiająca Świętą Rodzinę po narodzeniu Chrystusa. Wewnątrz nadrukowano tekst życzeń w języku hiszpańskim („Feliz Navidad y Próspero Año Nuevo").

$1 \quad$ Tekst zapisany na drugiej stronie kartki.

2 Kolorem czerwonym.

Wielce Szanowny i Drogi Panie,

Wstrzymywałem się z pisaniem do Pana, a to wyczekując, czy nie nadejdzie p i e r ws zy (drugi dostałem) list Pana, który mógł się zawieruszyć w bezmiarze świąteczno-noworocznych przesyłek pocztowych. Wciąż jednak nie nadchodzi i chyba już nie nadejdzie, - musiał zaginąc nie do odnalezienia.

Uwagi Pana na marginesie moich książek na og ół (w szczególności w związku z problemem „nie-typowości” fascynacji bosych stóp kobiecych) są niezmiernie trafne, choć nawet ten problem nie wydaje mi się być całkowicie „załatwiony” przez Pana, - nadawałby się bowiem do dalszej dyskusji na temat „typowości” jako „cnoty" w literaturze...

Co przecież szczególnie mnie uderzyło, to sygnalizowana mi przez Pana „bezradność” Pańska wobec Części II Stowa i ciała... A przecież - wydaje mi się - „klucz” do tej właśnie części jest jasny i prosty: przedstawia ona chrześcijaństwo (szczególnie chrześcijaństwo w świecie antycznym) jako „sprzysiężenie” mieszańców... Zwracam Pańską uwagę na motyw rozbicia przez filantropię chrześcijańską strajku tragarzy czy zwrot: „Czy to nie nie wo ln ik doniósł władzom, że jego pan, Apolonios, przynależy do Trzeciej Rasy?” A już przede wszystkim na uboczny pozornie motyw starotestamentowego Nehemiasza...

Przestrzegam, że w stosunku do Pana łamię - nie pierwszy, zresztą, raz - swoją zasadę: „Autorowi nie wolno komentować własnej książki”.

Prolog do powieści bizantyńskiej nie jest rzeczą w sobie zamkniętą, ale właśnie Prologiem tylko... Odstawiłem jednak pracę nad „powieścią bizantyńską” - nie wiem, czy na zawsze, czy na czas jakiś tylko; pracuję teraz nad Nową baśnia \{w której 
chcę przedstawić nową interpretację (jakże właśnie „baśniową” dla wielu czytelników i krytyków) tajemnicy Graala...

\{Dłoń Pańską ściskam mocno, - szczerze oddany, - Teodor Parnicki\} ${ }^{1}$

\{PS. - Załączam swoją fotografię, - ewentualnie do reprodukcji. Jeśli chodzi o informacje biograficzne, - myślę, że może Pan wykorzystać te, które znajdują się na wewnętrznych skrzydełkach obwoluty czwartego (drugiego w PAX'ie ${ }^{2}-z$ roku $1957^{3}$ ) wydania Aecjusza. - T. P. $\}^{4}$

List na dwóch kartach cienkiego, niebieskiego papieru lotniczego, zapisanych jednostronnie granatowym i czerwonym atramentem. W lewym górnym rogu s. 2 naniesiono rzymską cyfrę.

1 Tekst zapisany na marginesie s. 2 kolorem czerwonym.

2 PAX był wydawcą większości książek Parnickiego. Sytuacja polityczna PAX-u była skomplikowana i zmieniała się przez lata. Zasadniczo PAX prezentował stanowisko kompromisowe wobec władz komunistycznych, co w efekcie pozwoliło na wydawanie nie tylko książek, ale także prasy - „Słowa Powszechnego” czy „Kierunków”. Po roku 1989 funkcjonuje jako Katolickie Stowarzyszenie „Civitas Christiana”.

3 T. Parnicki, Aecjusz, ostatni Rzymianin. Wyd. 4. Warszawa 1957.

4 Tekst zapisany na marginesie s. 1.

4

19 listopada 1960

Wielce Szanowny i Drogi Panie,

Na wiosnę bieżącego roku wymieniliśmy z Panem listy w związku z planowaną przez Pana publikacją, poświęconą mojej pracy pisarskiej (miało to wyjść w „Pallotinum”). Czy zaniechał Pan tego zamiaru, czy też publikacja ta ukazała się, względnie ukaże się, i jeśli tak, to kiedy?

Będę Panu bardzo wdzięczny, jeśli zechce Pan łaskawie zaraz po ukazaniu się posłać mi do Meksyku 5 (pięć) egzemplarzy jej (bez względu \{na to, czy będzie to osobna książka 〈raczej książeczka〉, czy tylko rzecz wydrukowana w piśmie periodycznym) poczta p ol e c o na lotnic za. Koszta i tych 5 egz[emplarzy], i przesyłki zostaną Panu zwrócone na moje zlecenie - bardzo prędko - najpewniej przez PAX.

\section{Dłoń Pańską ściskam mocno - Teodor Parnicki $\left.{ }^{1}\right\}^{2}$}

List na jednej kartce cienkiego, niebieskiego papieru lotniczego, zapisanej jednostronnie granatowym i czerwonym atramentem. U góry stronicy widnieje pieczątka $z$ meksykańskim adresem nadawcy: Teodor Parnicki, Paseo de la Reforma 237 Apt. 17, Mexico 5, D. F., Mexico.

1 Kolorem czerwonym.

2 Tekst zapisany na marginesie stronicy.

[grudzień 1960]

Najserdeczniejsze Życzenia na „Gwiazdkę” i Rok 1961 przesyła Panu, łącząc moc miłych pozdrowień

Teodor Parnicki 
Składana kartka świąteczna. Na s. 1 widnieje grafika przedstawiająca meksykańskiego chłopca. Wewnątrz, granatowym atramentem słowa zapisane przez Parnickiego.

28/VII 1961

Wielce Szanowny i Drogi Panie,

Dawnośmy nie wymieniali z sobą listów. Zapewne PAX (dawno im już to zleciłem!) przesłał Panu Twarz księżyca ; ja - w międzyczasie - ukończyłem dla PAX'u Część II-ga Twarzy księżyca ${ }^{2}$ (wejdzie w jej wydanie ksiażkowe Prolog do powieści bizantyńskiej, znany Panu w odcinkach w „Kierunkach” w r. 1957², - ukaże się podobno jeszcze w końcu br.), - oraz dla PIW'u, część I-szą Nowej baśni (wyjdzie z początkiem r. 1962).

Mam do Pana wielką prośbę: we Wrocławiu właśnie ukazywały się n i e z b ę d n e dla mnie teraz (w „Myśli Karaimskiej” ${ }^{2}, 1946^{6}$ i w pracach wrocławskiego T-wa Naukowego 19467 ) prace naukowe Ananiasza Za jac c z k o w s k i e g o ${ }^{8}$ o Chazarach ${ }^{9}$. Czy mógłby Pan zdobyć je dla mnie (i posłać mi), - ewentualnie $\mathrm{z}$ pomoca mego serdecznego przyjaciela $\mathrm{z}$ lat przedwojennych, p. Tadeusza $\mathrm{B}$ a $\mathrm{n}$ as i a ${ }^{10}$, Kierownika Programów (czy redakcji) wr o cła w s k i ej rozgłośni Polskiego Radia? Ogromnie byłbym Panu wdzięczny!

Myślę, że zna Pan osobiście (z Warszawy) Jerzego Jana Pi e c h ow s k i e g o ${ }^{11}$. Przeczytałem w maszynopisie jego powieść historyczną Twarze na ścianach ${ }^{12}$. Jedna książka nie czyni pisarza (jak jedna jaskółka - wiosny), - ale jeśli Piechowski będzie konsekwentnie szedł dalej tą samą drogą, na którą wkroczył Twarzami na ścianach, - dostrzegam w nim materiał na powieściopisarza historycznego $\mathrm{kla} \mathrm{sy}$ (i artystycznie, i intelektualnie) niewątpliwie wyższej niż moja własna. \{Dłoń Pańską ściskam serdecznie, - Teodor Parnicki\} ${ }^{13}$

\{PS. ${ }^{14}$ Czy spotyka Pan we Wrocławiu muzykologa-pianistkę, panią Jadwigę Szajna-Lewandowską ${ }^{15}$ ? Jeśli tak, - proszę poprosić ją o list do mnie, lub przynajmniej o adres. $\}^{16}$

List na jednej karcie, zapisanej obustronnie granatowym i czerwonym atramentem. U góry stronicy widnieje pieczątka $\mathrm{z}$ meksykańskim adresem nadawcy.

$1 \quad$ T. Par n i cki, Twarz księżyca. Powieść z wieków III-IV. Cz. 1. Warszawa 1961.

2 T. Parni cki, Twarz księżyca. Opowieść bizantyńska z roku 450. Cz. 2. Warszawa 1961.

3 T. Parn i c ki, Prolog do opowieści bizantyńskiej. „Kierunki” 1957, nry 73-79. Ilustracje wykonał

Z. Padowicz. W siedmiu odcinkach wydrukowano cały Prolog, który w wydaniu książkowym zajmuje 90 stronic.

4 T. Parnicki, Nowa baśń. Cz. 1: Robotnicy wezwani o jedenastej. Warszawa 1962.

5 „Myśl Karaimska” - czasopismo o profilu naukowym, społecznym i literackim, traktujące o mniejszości Karaimów w Polsce. Ukazywało się w latach 1924-1947, następnie przekształciło się w „Przegląd Orientalistyczny".

6 W „Myśli Karaimskiej” z roku 1945/46 ukazał się (w z. 1) artykuł A. Zaj ą c z k o w s ki e go O kulturze chazarskiej i jej spadkobiercach.

7 W latach czterdziestych i pięćdziesiątych Wrocławskie Towarzystwo Naukowe opublikowało kilka prac A. Zają czkows ki e go: Głosy tureckie w zabytkach staropolskich (I Katechizacja turecka J. Herbiniusa z r. 1675) (1948); Zwiazki językowe połowiecko-słowiańskie (1949); Studia orientali- 
styczne z dziejów słownictwa polskiego (1953). Ale najprawdopodobniej chodzi o pozycję Ze studiów nad zagadnieniem chazarskim (Kraków 1947), ogłoszoną jednak przez wydawnictwo Polskiej Akademii Umiejętności.

8 Ananiasz Zają c z k ow ski (1903-1970) - polski badacz, orientalista, działacz karaimski, profesor Uniwersytetu Warszawskiego, w latach 1931-1947 redaktor „Myśli Karaimskiej”.

9 Chazarowie to lud pochodzenia tureckiego, z okolic Kaukazu, Morza Czarnego i Morza Azowskiego, prowadzący nomadyczny tryb życia. Być może, jego potomkami są właśnie Karaimi. Chazarem jest Łukasz biskup Nowogrodu - bohater Nowej baśni.

10 Tadeusz Ban aś (1908-1993) - przyjaciel Parnickiego z lat lwowskich, ukończył polonistykę na Uniwersytecie Jana Kazimierza we Lwowie. Po wojnie zastępca redaktora naczelnego do spraw programów artystycznych Radia Wrocław.

11 Jerzy Jan Pi e c h o w s k i (1936-2003) - pisarz i eseista. Ukończył filologię klasyczną na Uniwersytecie Warszawskim. Publikował w „Kierunkach”, „Słowie Powszechnym” i w miesięczniku „Życie i Myśl". Otrzymał stypendium od Parnickiego, które ten ufundował dla młodych prozaików. Laureat Nagrody Młodych im. Włodzimierza Pietrzaka (1967). Autor wielu powieści historycznych. Trudno określić, o jaką powieść chodzi, debiutem J. J. Piechowskiego był Cień sprawy (Warszawa 1962).

13 Tekst zapisany na marginesie s. 2 kolorem czerwonym.

14 Kolorem czerwonym.

15 Jadwiga Szajna-Lewandowska (1912-1994) - kompozytorka, pianistka i nauczycielka, znajoma Parnickiego $\mathrm{z}$ lat lwowskich.

16 Tekst zapisany na marginesie, a potem u góry s. 1.

Wielce Szanowny i Drogi Panie,

Nie jestem pewien, czy i nadal ma Pan ten sam adres prywatny (W r o cła w, 8, Asnyka 17), - więc wysyłam ten list do Krakowa, na adres „Tygodnika Powszechnego".

Przeczytałem właśnie wycinek $\mathrm{z}$ tego pisma $\mathrm{z}$ Pańskim obszernym artykułem Oblicza księżyca ${ }^{1}$, - myślę, że nikt nie wnika w moje pisarstwo tak, jak Pan; wnika w nie, owszem, Witold Billip ${ }^{2}$, - jest przecież (mówi, że jest, - w listach do mnie) marksistą, i zdaje się, to właśnie sprawia (ale czy musi sprawiać?), że jak napisał niedawno do mnie - trudno od niego spodziewać się, by mógł się pasjonować zmaganiami między monofizytami a diofizytami ${ }^{3}$... Pan przecież - ze wzruszeniem to stwierdzam - może właśnie tym pasjonować się, - a przynajmniej rozumieć moją pasję... Może jeszcze głębiej wzruszyło mnie zwrócenie przez Pana uwagi (wraz z zasygnalizowaniem, - ską d to w mych książkach wzięło się) na „Ojca ojciec i ojca dziad”4, - przede wszystkim zaś, - na Maksymianowe „Do krwi ostatniej kropli z żył" ${ }^{\prime}$... Tyle literatura polska uwagi poświęca motywowi miłości do kobiety, - ja niby poświęcam mało (szczególnie w ostatnich książkach), - przecież pochlebiam sobie, że owym „Do krwi ostatniej kropli, - etc.”, - Maksymian nie daje się zdystansować - właśnie, o ile chodzi o motyw miłości ${ }^{6}$ - Skrzetuskiemu, Wołodyjowskiemu, \{Rafałowi Olbromskiemu, Doktorowi Judymowi... - „Przeraźliwość” teologizowania Ewangelii?! $!^{7}$ Chodziłem do gimnazjum w Charbinie [!] (Mandżuria) - gimnazjum było przykościelne i dosłownie (odległość w metrach), CD. na odwrocie $^{8} /$ CD. z odwrotu ${ }^{9}$ i w tym sensie, że właściwie (choć nie formalnie) kierowali nim księża ${ }^{10} \ldots$ Z Ewangeliami było się tam lepiej obytym (a i z liturgiką) niż z za- 
sadami funkcjonowania ${ }^{11}$ telegrafu czy algebraicznym rozkładaniem na czynniki pierwsze, - otóż zapewne znów wzdrygnie się Pan, ale już właśnie w gimnazjum nic z Ewangelii nie fascynowało mnie tak, jak „Nim Abraham był, jam jes t” $^{12}$ (a na drugim miejscu: „Tobie dam klucze królestwa niebieskiego - cokolwiek rozwiążesz na ziemi" 13 , - etc., etc.)

\section{Dłoń Pańską ściskam najserdeczniej, - Teodor Parnicki\} ${ }^{14}$}

List na jednej karcie, zapisanej obustronnie granatowym i czerwonym atramentem. U góry stronicy widnieje pieczątka z meksykańskim adresem nadawcy.

1 J. Łuka siewi cz, Oblicza księżyca. „Tygodnik Powszechny” 1962, nr 23, s. 5. Przedruk w: Republika mieszańców (1974).

Witold Billip (1931-1991) - krytyk literacki, związany głównie z „Nowymi Książkami”.

3 Monofizytyzm, głoszący, iż Boska natura Chrystusa wchłonęła naturę ludzką, został potępiony jako herezja przez Sobór Chalcedoński w 451 roku. A według doktryny chrystologicznej diofizytyzmu (przyjętej na tym samym soborze) Chrystus posiada dwie oddzielne natury: Boską i ludzką, złączone w unii hipostatycznej. Zob. B. K u m or, Historia Kościoła. T. 1: Starożytność chrześcijańska. Wyd. 2, zmien. Lublin 2003.

4 Fragment utworu Do moich synów J. Żuławski ego (w: Wiersze. Wybór, wstęp A. Z. Makowi e c ki. Warszawa 1982, s. 224). Pierwsza strofa brzmi:

Synkowie moi, poszedłem w bój, jako wasz dziadek, a ojciec mój, jak ojca ojciec i ojca dziad, co z Legionami przemierzył świat szukając drogi przez krew i blizny do naszej wolnej Ojczyzny!

5 Cytat pochodzi z drugiej strofy Roty M. Konopnickiej (w: Wiersze wybrane. Wybór, wstęp A. Kamieńska. Warszawa 1965, s. 167):

Do krwi ostatniej kropli z żył

Bronić będziemy ducha,

Aż się rozpadnie w proch i w pył

Krzyżacka zawierucha.

Maksymian - bohater Parnickiego - kochał Storację.

Zob. Łu ka si ew ic z, Oblicza księżyca, s. 5: „Jest w powieści coś przerażającego w tym teologizowaniu Ewangelii i używaniu, a także nadużywaniu teologii we wszelkich możliwych poczynaniach”. Kolorem czerwonym.

Kolorem czerwonym.

W Harbinie (dawniejsza pisownia: Charbin), gdzie działała kolonia polska, przebywał Parnicki w latach 1920-1928. Uczęszczał do gimnazjum im. Henryka Sienkiewicza, kierowanego przez ks. Władysława Ostrowskiego. Okres ten jest niezwykle ważny, ponieważ właśnie w Harbinie Parnicki miał zacząć naukę języka polskiego oraz postanowić, że zostanie polskim pisarzem powieści historycznych.

Kolorem czerwonym.

Pismo Święte Starego i Nowego Testamentu w przekładzie z języków oryginalnych (Oprac. Zespół Biblistów Polskich [...]. Biblia Tysiaclecia. Wyd. 3, popr. Poznań 1990. Wszystkie fragmenty cytuję według tej edycji Pisma Świętego) podaje: „Rzekł do nich Jezus: "Zaprawdę, zaprawdę, powiadam wam: Zanim Abraham stał się, JA JESTEM" (J 8, 58). Arianie (potępieni przez Sobór Nicejski w 325 roku) twierdzili odwrotnie: Chrystus miał zostać stworzony przez Boga, a więc był czas, gdy Go nie było (zob. Ku mor, op. cit.). O teologii pisania i teologii w powieściach Parnickiego zob. J. Łu k a s i e w i c z, „Pomnożyciel lat jego”... Teoria literatury, czyli teologia. W zb.: Świat Parnickiego. Materiały z konferencji. Red. ... Wrocław 1999, s. 188-189.

Czytamy w Ewangelii według św. Mateusza (16, 18-19): „Na to Jezus mu rzekł: „Błogosławiony jesteś, Szymonie, synu Jony. Albowiem nie objawiły ci tego ciało i krew, lecz Ojciec mój, który jest w niebie. Otóż i Ja tobie powiadam: Ty jesteś Piotr 〈czyli Skała〉, i na tej Skale zbuduję Kościół mój, a bramy piekielne go nie przemoga. I tobie dam klucze królestwa niebieskiego; cokolwiek 
zwiążesz na ziemi, będzie związane w niebie, a co rozwiążesz na ziemi, będzie rozwiązane w niebie«". Wedle tradycji ten fragment jest niezwykle ważny w kontekście utworzenia Kościoła przez Jezusa oraz nadania władzy nad nim św. Piotrowi. To często powracający temat w powieściach Parnickiego.

14 Tekst zapisany kolorem czerwonym na marginesach s. 2, potem 1 i w końcu u góry s. 1.

Wielce Szanowny i Drogi Panie,

Dziękuję Panu serdecznie za miły i interesujący list z 15 lipca. Jest Pan naprawdę przesadnie skromny!

Gdyby miało się - zgodnie z tym, co Pan sam właśnie pisze - założyć, że nie rozumie Pan należycie Twarzy księżyca czy w ogóle moich „Światów mieszańców”, - to trzeba byłoby powiedzieć, że - w takim razie - nikt ich nie rozumie, nie wyłączajac... autora samego!

\{Czy mógłby mi Pan posłać ze 3 egzempl[arze] „Tygodnika Powszechn[ego]” z Pańskim artykułem o Słowie i c[iele] $]^{1}$ - i 5 egz[emplarzy] z Pańskim artykułem

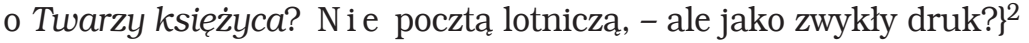

Bo np. artykuł Tomasza Burka ${ }^{3}$ w „Twórczości”4 . Jest to bezsprzecznie ś w i e tny komentarz, ale właśnie komentarz raczej aniżeli recenzja, o ile nazwą „recenzji” określić należy (a sądzę, że należy) rozprawę krytyczną mającą na celu nie tylko referowanie, ale i wartościowanie. Bo pomijając już nawet pewną „bladość” końcowych wniosków Burka, - trudno mi zgodzić się z nim w ocenie głównych postaci w tomie II Twarzy księżyca. Oczywiście, - w pełni uznaję, że postacie - gdy raz wyszły spod pióra autora i „poszły w świat” - mają swe autonomiczne życie i któryś krytyk czy czytelnik może dostrzec w nich to, co nie było dostrzegalne dla autora samego...

Nie spierałbym się, co prawda, z Burkiem, może ${ }^{5}$, gdy chodzi o jego odczucie Rufusa czy nawet Storacjusza, - ale uważam, że Maksymiana jego zreferowanie stanowczo „krzywdzi”, - i Pańskich kilka słów o tymże Maksymianie wydają mi się być bliższe prawdy - jeśli i nie o Maksymianie „autonomicznie” właśnie już żyjącym, - ale takim, jakim się przedstawia on mnie samemu (świetna też jest Pańska - znowuż w kilku słowach - definicja osobowości Sykoriusza Probusa) ${ }^{6}$.

Teraz, co do Nowej baśni. W moim własnym rozumieniu i odczuciu, - „nowoba ś ni o w o ś ć" mniej dotyczy sprawy wypraw do Ameryki w XI-XII w., - co motywu Stanisława i Eryka. W zasadzie można zało ży ć, że Eryk uderzył Stanisława toporem w głowę w kwietniu 1079, - i że wszelkie jego dalsze „kontakty” ze Stanisławem to tylko „urojenia”, - następstwo wyrzutów sumienia ${ }^{7}$. Oczywiście, - co do tej sprawy w powieści jest dwuznaczność, - ale przecież dwuznaczność panuje w całej tradycji o św. Stanisławie, a i w samym przekazie Gallusa...

Ktoś z moich bliskich przyjaciół, wielkich, zresztą, miłośników moich książek, napisał $\mathrm{mi}^{8}$, „Nowa baśnią zaszargałeś nam (tj. nam, Polakom) tysiąclecie i spaskudziłeś świętego biskupa"9. Było to napisane niby półżartem, ale właśnie tylko pół żartem, - czyli na wpół na serio... Czy podzielałby Pan taką opinię? Czy sądzi Pan, że wiele osób wśród Polaków podzielałoby ją?

Zastanowiło mnie to, co Pan napisał o fascynacji, jaką ma mieć dla mnie wła- 
dza absolutna. Ciekawym, co Pan - właśnie w związku z tym Pana ujęciem - powie o moim papieżu Janie XXII ${ }^{10}$ (awiniońskim) \{w Tylko Beatrycze, którą to książkę właśnie skończyłem pisać, wyjść ma w PAX'ie, może jeszcze przed upływem roku 1962.

\section{Dłoń Pańską ściskam najserdeczniej, - Teodor Parnicki $\left.{ }^{11}\right\}^{12}$ \\ \{Doszło do mnie, że miał Pan w Krakowie wykład o moich książkach. Bardzo mnie to ucieszyło - że w ogóle wykład, - a szczególnie, że w Krakowie, do którego mam wiele sentymentu. $\}^{13}$}

List na jednej karcie zapisanej obustronnie granatowym i czerwonym atramentem.

J. Łuk k siewicz, Stowo i ciało. „Tygodnik Powszechny” 1960, nr 50, s. 4.

Tekst zapisany na marginesie s. 1 .

T. B u r ek, Świat niewymierny Teodora Parnickiego. „Twórczość” 1962, nr 6. Szkic ten wszedł później w skład wydania książkowego: T. Bu rek, Zamiast powieści. Warszawa 1971.

4 „Twórczość” w tym czasie wychodziła pod redakcją J. Iwaszkiewicza.

5 Kolorem czerwonym.

$6 \quad$ Zob. Łukasiewicz, Oblicza księżyca.

7 Inne odczytanie mogłoby pójść w stronę „wędrówki dusz”, zob. list 9.

8 Chodzi najprawdopodobniej o Andrzeja Ma d e y s k i e go - architekta i przyjaciela pisarza, mieszkającego w Montrealu. Parnicki spotkał się z nim w Meksyku. Zob. T. Marki e w ka, „Nie istnieje PERPETUUM MOBILE". Listy Teodora Parnickiego do Andrzeja Madeyskiego z lat 1957-1988 (fragment). „FA-art” 2008, nr 4, s. 99 (tu list T. Parni cki g o do Madeyskiego z 29 VII 1962).

9 Wedle Nowej baśni biskup Stanisław miał być dzieckiem Bolesława Chrobrego i Przecławy, kijowskiej księżniczki, poczętym wskutek gwałtu w 1018 roku. Zob. Parni cki, Nowa baśń, cz. 1. F. Mazurki ewicz, Podróż na Atlantydę. O I tomie „Nowej baśni” Parnickiego. Katowice 2012. Sam Parnicki wracał do tego tematu, poświęcił mu część jednego ze swoich wykładów - zob. Parn i c ki, Historia w literature przekuwana. Prolog J. Z. J a k u b o w s ki. Warszawa 1980, s. 390-403.

10 Jan XXII (zm. 1334) - właśc. Jacques Duèse (ok. 1244-1334) - papież z okresu „niewoli awiniońskiej”, bohater powieści Tylko Beatrycze. Miał uważać, że piekło nie istnieje, ale został zmuszony do odwołania swoich poglądów przed śmiercią. Jest to jeden $\mathrm{z}$ ważnych wątków powieści. Jego postać pojawia się później w powieści „Zabij Kleopatrę”.

11 Kolorem czerwonym.

12 Tekst zapisany na marginesie i u góry s. 2.

13 Tekst zapisany u góry s. 1 kolorem czerwonym. Trudno ten fragment przyporządkować jednoznacznie (co u Parnickiego rzadkie) do określonego miejsca w treści listu. Najpewniej pełni funkcję postscriptum.

Wielce Szanowny i Drogi Panie,

Dziękuję Panu serdecznie za miły i - jak zawsze - wiele dający mi list. Tom drugi Nowej baśni jest już w redakcyjnym opracowaniu w PIW'ie'; nie myślę jednak, by się ukazał przed późną wiosną 1963; natomiast Tylko Beatrycze w PAX'ie ${ }^{2}$ ma wyjść tuż po Bożym Narodzeniu, i, oczywiście, zlecę PAX'owi, by zaraz posłali Panu egzemplarz. Przygotowuję się teraz do pisania III tomu Nowej baśni $i^{3},-$ będzie tam chyba więcej jeszcze niż w tomach I i II, - „podróży” - nie tyle przestrzennych, co „с z a s o przestrzennych” (np. Nowogród biskupa Łukasza „жидяты” 〈vide tom I〉) i Nowogród też z czasów ruchu religijnego „жидоветвующий" 
niec w. XV - pocz[ątek] XVI (zresztą, nie tylko Nowogród, ale i Moskwa). Takie „podróże c z a s o przestrzenne” (te z tomu I na razie) wywołują u krytyków - stwierdziłem - nieporozumienia, np. przypisują mi niektórzy sięgnięcie po motyw „wcieleń”, „wędrówki dusz”, - etc. Absurd! Wspomniał Pan w swym liście Stefana Lichańskiego ${ }^{6}$, - nie znam jego adresu, więc byłbym Panu gorąco wdzięczny za przekazanie mu ode mnie wiadomości, że sprawił mi on ogromna przyjemność w swym artykule o Nowej baśni („Za i Przeciw”, 30/IX 62) ${ }^{7}$ uwypukleniem istotnego sensu mianowicie ${ }^{8}$, iż chodzi mi o „dziedzictwo idei”, - a nie o żadną „wiarę w wędrówkę dusz"...

Czy widział Pan recenzję Billipa w „Nowych Książkach”? - wynikałoby z niej (wbrew domysłowi Pana w ostatnim liście), że marksiści zżymają się raczej na typ dialektyki właściwy historiozofii Nowej baśni. Dłoń Pańską ściskam serdecznie,

\section{- T. Parnicki ${ }^{10}$}

\section{Kartka II - 21/XI $1962^{11}$}

PS. ${ }^{12}$ Miałbym do Pana wielka prośbę: czytałem przed kilkoma tygodniami w „Tygodniku Powszechnym”, że któreś W-two katolickie (n i e PAX) wydało ostatnio przekład polskich Starożytności żydowskich Józefa Flawiusza ${ }^{13}$. Czy mógłby Pan wystarać się dla mnie o tę książkę? Oczywiście, - poleciłbym PAX'owi zwrócenie Panu, możliwie zaraz, kosztów zarówno ceny książki, jak przesyłki jej do Meksyku. Z góry gorąco dziękuję, - przepraszam za kłopot, - T. P. ${ }^{14}$

List na dwóch małych kartkach, zapisanych (pierwsza dwustronnie, druga - jednostronnie) granatowym i czerwonym atramentem. Kartki są poprzecinane i podklejone.

T. Pa rnicki, Nowa baśń. Cz. 2: Czas siania i czas zbierania. Posł. A. J elicz. Warszawa 1963.

T. Parni cki, Tylko Beatrycze. Powieść historyczna. Warszawa 1962.

T. Parnicki, Nowa baśń. Cz. 3: Labirynt. Warszawa 1964.

Żydiaty (ros.) - chodzi o biskupa Nowogrodu, Łukasza Żydziętę, bohatera pierwszego tomu Nowej baśni. Łukasz był Chazarem, a ci wyznawali judaizm - stąd jego przezwisko.

Żydowietwujuszczyj (ros.) - żydopodobny.

6 Stefan Lichański (1914-1983) - krytyk literacki i tłumacz. Ukończył polonistykę na Uniwersytecie Łódzkim, doktoryzował się na Uniwersytecie Warszawskim. Debiutował przed wojną w „Pionie”, więzień w Oświęcimiu. Po wojnie związany m.in. z „Twórczością”, „Dziś i Jutro” i „Kierunkami”, w tym czasie pracował w PIW-ie (wydawca Nowej baśni Parnickiego).

S. Li ch ań ski, Nowa baśń. „Za i Przeciw” 1962, nr 40, s. 10.

Kolorem czerwonym.

W. Billi p, Parnickiego baśń dla dorostych. „Nowe Książki” 1962, nr 16.

Kolorem czerwonym.

1 Kolorem czerwonym. Prawdopodobnie któraś z dat - ta lub podana na pierwszej stronicy listu - jest błędna. Nic nie wskazuje na to (nawet identyczne na obu kartkach przecięcie o specyficznym kształcie „kielicha”), aby pierwsza część listu z listopada miała się zagubić.

Kolorem czerwonym. d oży cki. Poznań 1962). Książka ukazała się w katolickim wydawnictwie Księgarnia św. Wojciecha.

Kolorem czerwonym. 
Kochany Panie Jacku,

Wyjechaliśmy z Gdyni o 5-tej rano ${ }^{1}$, w sobotę 11 kwietnia statkiem „Norwid”, - „na starych śmieciach" w México D. F. jesteśmy od 19 maja. Omalże zaraz zabrałem się do pracy nad powieścią $I$ u możnych dziwny ${ }^{2}$ (tytuł, $-z$ pierwszego kazania sejmowego Skargi ${ }^{3}$ ), - o której to powieści wiele z Panem mówiliśmy; \{Młodość Zagłoby, związana ściśle ze Stowarzyszeniem Jezusowym; członkiem przecież Stowarzyszenia zostać n i e mógł, bo miał jednego z pradziadów Żyda (ś c i śl le historyczne: od tak zwanego "raportu Aleksandra Valignano" ${ }^{4}$, potomkowie nowych chrześcijan nie mogli być członkami Stowarzyszenia $\left.{ }^{5}\right\}^{6}$ właśnie s k o ń c zy ł e m ją pisać; pisząc, - nieraz myślałem o Panu; zawsze muszę, pisząc, wyobrażać sobie „idealnego czytelnika”, - a takim był Pan właśnie, gdym pisał tę książkę... Zastanawiałem się nawet nad tym, żeby tę książkę dedykować Panu, - ale się z tego zamiaru wycofałem, czego - mam nadzieję - ni e weźmie mi Pan za złe... Bo oto tom III Nowej baśni (czy Pan już dostał egzemplarz? pisałem do PIW'u, by Panu posłali) dedykowałem Andrzejowi Kijowskiemu, na co kierownictwo naczelne redakcyjne PIW'u zgodziło się, - ale nie bez zastrzeżeń; mianowicie ukazano mi „niebezpieczeństwo” takich dedykacji: że niby ja „rozbrajam” krytyka dedykacja, a on się naraża na prawdopodobieństwo zarzutów, że „musi o Parnickim pisać dobrze, skoro Parnicki zadedykował mu książkę”... Może kiedyś przyjdzie czas ${ }^{7}$, gdy będę mógł jakąs książkę P a n u zadedykować (a bardzo bym tego pragnął), bez potrzeby obawiania się, iż w następstwie takiej dedykacji ktoś (ktokolwiek bądź) będzie myślał źle, zarówno o mnie, jak o Panu...

Mam o Panu (który ze „słowa” też się w „ciało” przeobraził8) \{jak najmilsze wspomnienia. I to wi elostronnie - bo wchodza w nie i kapuśniak, i pierogi, - na kolacji w domu Państwa we Wrocławiu, - i nasze rozmowy, i Pański czar osobisty... (A rozumie Pan chyba, że na „czar mężczyzn” jestem bard zo mało wrażliwy, w przeciwieństwie do niektórych $z$ naszych kolegów.)

Dłoń Pańską ściskam najgoręcej - Teodor Parnicki ${ }^{9}{ }^{10}$ \{Serdecznie pozdrawiamy, oboje z Elą ${ }^{11}$, - Pańską małżonkę, i syna, i nianię... $\}^{12}$

List na jednej karcie, zapisanej obustronnie granatowym i czerwonym atramentem.

1 Parnicki ma tu na myśli swoją pierwsza wizyte w Polsce, zorganizowana przez PAX w latach 1963-1964. Pisarz wspomina o niej w liście z opóźnieniem, będąc już z powrotem w Meksyku. Druga wizyta odbyła się na przełomie lat 1965-1966 (listy 12-15, z Warszawy). Parnicki przyjechał do Polski na stałe w roku 1967 (zob. list 21).

2 T. Parnicki, I u możnych dziwny. Powieść z wieku XVII. Warszawa 1965.

3 P. Skarga, Kazania sejmowe. Oprac. J. Tazbir, M. Korolko. Wyd. 4, uzup. Wrocław 1984, s. 5. BN I 70: „Przez nię będę miał sławę u ludzi, i uczczenie młodych od starych. I będę ostry w rozsądku, i u możnych dziwny".

4 Alessandro Valign a n o (1539-1606) - włoski jezuita, misjonarz działający na Dalekim Wschodzie i w Japonii.

5 Jan Onufry Zagłoba, i kilku innych bohaterów Parnickiego, nie może zostać członkiem Towarzystwa Jezusowego $\mathrm{z}$ powodu pochodzenia żydowskiego.

6 Tekst zapisany na marginesie s. 1. 
7 Czas ten nadszedł dopiero przy okazji Opowieści o trzech Metysach, wydanej w 1994 roku, po śmierci pisarza. Zob. list 5 E. Parnicki ej do Łukasiewicza (ze stycznia 1995).

8 Aluzja do Stowa i ciała - chodzi zapewne o to, że po wieloletniej wymianie listów Parnicki i Łukasiewicz w końcu się spotkali; w czasie tej wizyty trzykrotnie: raz we Wrocławiu, dwa razy w Warszawie.

9 Kolorem czerwonym.

10 Tekst zapisany na marginesie s. 2.

11 Eleonora Parni ck a (ur. 1922), z domu Kubińska, primo voto Grygier, była siostrzenica starosty nieświeskiego, z którym przybyła 17 IX 1939 na Litwę. Została wywieziona do Komi ASRR w 1941 roku. Pracowała w Delegaturze Ambasady RP w Syktywkarze. Więziona pod zarzutem szpiegostwa, została zwolniona dzięki interwencjom dyplomatycznym i wyjechała do Kujbyszewa w 1942 roku. Potem przeniosła się do Persji. W roku 1943 zaczęła pracę w MSW w Londynie, ukończyła ją w 1952 roku. Ślub z Parnickim wzięła 30 XI 1955 roku. Była druga jego żoną. W roku 1956 przyjechała do Meksyku. Żyje i mieszka obecnie w Warszawie.

Tekst zapisany u góry s. 1 kolorem czerwonym, pełni najpewniej funkcję postscriptum.

Kochany Panie Jacku,

Ślę wiele najserdeczniejszych życzeń na święta i Nowy Rok dla Pana z rodziną (i z gosposia), - a za Pańskim łaskawym pośrednictwem, - dla pp. Mazowieckich ${ }^{1}$, Esków ${ }^{2}$ i Krzysztoniów ${ }^{3}$ oraz dla tych Państwa ${ }^{4}$ (przykre to, ale „wyleciało” mi nazwisko z głowy), z którymi byliśmy u Państwa „na kapuśniaczku i pierogach” w styczniu $1963^{5}$.

\section{Szczerze Panu oddany, - Teodor Parnicki ${ }^{6}$}

Kartka pocztowa. Na s. 1 widnieje grafika przedstawiająca scenę $\mathrm{z}$ konkwisty Meksyku z XVI wieku, $z$ udziałem Ferdynanda Corteza i Bartolomégo de Las Casas (według informacji nadrukowanej na kartce). Na s. 2 słowa skreślone przez Parnickiego granatowym i czerwonym atramentem.

$1 \quad$ W spotkaniu u Parnickich wzięli udział m.in.: Tadeusz Mazowiecki z drugą żona - Ewą.

2 Juliusz E s ka (1927-1997) - publicysta, związany z PAX-em i z „Więzią”, a także z Klubem Inteligencji Katolickiej. Na spotkaniu obecna była również jego żona - Donata.

3 Jerzy Krzysztoń (1931-1982) - prozaik, dramaturg i tłumacz. Po wojennej tułaczce (Azja, Afryka) wrócił z rodziną do Polski w 1948 roku, ukończył polonistykę i anglistykę na Katolickim Uniwersytecie Lubelskim. Do roku 1956 związany ze stowarzyszeniem PAX. Pracował w Polskim Radiu. Na spotkaniu była obecna także jego żona - Halina Kr zy s z t oń (z d. Panfiłowicz).

4 Słowa te odnoszą się do Urszuli Ko zi oł i jej męża, Feliksa Pr zy by la k a (1933-2010) - pisarza, literaturoznawcy i tłumacza języka niemieckiego. W późniejszym czasie został on wykładowcą i profesorem Uniwersytetu Wrocławskiego.

5 Chodzi o spotkanie we Wrocławiu w trakcie pierwszej wizyty pisarza w kraju (zob. list 10). Parnicki pomylił się z datą roczną - spotkanie musiało odbyć się w styczniu 1964 (Parniccy przypłynęli do Polski 12 XI 1963).

6 Kolorem czerwonym. 
Drogi Panie Jacku,

Telefonowałem do Pana - o ile się nie mylę - w niedzielę 7 listopada; Pani Teresa powiedziała, że jest Pan w Dreźnie, więc pozwoliłem sobie ją prosić, by zanotowała nasz nowy adres i telefon (Warszawa, ul. Miodowa $23 \mathrm{~m}$. 16 - telef[on] 31-42-22) ${ }^{1}$. Oczekiwałem Pana w Warszawie około 10/XI - nie pojawił się Pan; nazajutrz dzwoniłem do „Więzi” i powiedział mi p. Makinowski [! $]^{2}$, że oni też na Pana „niecierpliwie, a jak dotąd, bezskutecznie" czekają... Nie potrzebuję chyba dodawać, że i ja też czekam na Pana (a to właśnie na nowym mieszkaniu - na Miodowej) co najmniej ró w n i e niecierpliwe, a mam nadzieję, że nie okaże się to „bezskuteczne” czekanie...

W Krakowie miałem n a d z wy c zaj interesujacy wieczór „intymny”3 z Malewską $^{4}$, Gołubiewem i Woźniakowskim - w domu pp. Gołubiewów ${ }^{5} . .$.

Jeszcze pytanie: czy \{nie Pan to pożyczył ode mnie Kosmos Gombrowicza? Oboje z Elą dla obojga Państwa ślemy moc serdeczności - Teodor Parnicki. $\}^{6}$

List na jednej karcie, zapisanej obustronnie granatowym atramentem.

1 To adres, pod jakim Parniccy mieszkali w trakcie swojego drugiego pobytu w Warszawie, zorganizowanego przez PAX, na przełomie lat 1965 i 1966.

2 Chodzi o Stefana Bakin ow s ki e go - wówczas członka kolegium redakcyjnego „Więzi”.

3 Zob. T. Parnicki, Opowieść o trzech Metysach. T. 1: Raczej jednak oni. Warszawa 1992, s. 259264.

4 Warto tu nadmienić, że T. Pa rn i cki pisał o książkach H. Malewskiej: Problem władcy we wspótczesnej powieści historycznej i biograficznej. (Na marginesie ksiażki H. Malewskiej „Żelazna korona”). „Przegląd Powszechny” 1937, nr 7/8. Zob. też korespondencję: „Przy całej odmienności naszych postaw pisarskich..." Listy Teodora Parnickiego do Hanny Malewskiej z lat 1960-1974. Oprac. A. Dobrow olski. „Pamiętnik Literacki” 2003, z. 1

5 Przebieg tego spotkania stanie się jednym z tematów Opowieści o trzech Metysach.

6 Tekst zapisany na marginesie s. 2.

Warszawa, ul. Miodowa 23 m. 16.

16/XI 1965

Drogi Panie Jacku,

W nawiązaniu do listu, który wysłałem Panu wczoraj, - śpieszę donieść, że już po wrzuceniu owego listu do skrzynki stwierdziłem, że Kosmos został pożyczony ode mnie przez Andrzeja Piotrowskiego.

A jak wygląda sprawa wyboru przez Pana fragmentu z tomu IV Nowej baśni (Gliniane dzbany ${ }^{1}$ ) dla „Więzi”? Czy Pan już był łaskaw dokonać tego wyboru? Czy odnośny fragment został już przez Pana do redakcji „Więzi” przesłany?

Najserdeczniej dłoń Pańską ściskam Teodor Parnicki

List na jednej karcie, zapisanej obustronnie granatowym atramentem.

1 T. Parnicki, Nowa baśń. Cz. 4: Gliniane dzbany. Warszawa 1966. 
Drogi Panie Jacku,

Dziękuje gorąco za sugestie w sprawie rozpoczęcia zabiegów o mieszkanie dla nas we Wrocławiu, ale myślę, że byłyby to chyba zabiegi stanowczo przedwczesne, bo oto nie jest wyłączone, iż wyjechalibyśmy (może wiosną r. 1966) znów do Meksyku, z tym przecież, że po jakimś czasie znów chyba do Polski wrócilibyśmy. Dziękuję też Panu za przekazanie osobiste Hannie Malewskiej wypowiedzi z mej strony $\mathrm{w}$ sprawie oporów moich co do eseistyki. $Z$ „Więzi” (owszem, przeczytałem interesująca, choć może nazbyt „dygresyjną” recenzję Szpotańskiego ${ }^{1}$ ) nie dostałem ani maszynopisu, ani wiadomości, jaki ostatecznie fragment z tomu IV Nowej baśni postanowili wydrukować, - może Pan wie coś o tym?

A czy był Pan łaskaw dowiadywać się w antykwariatach we Wrocławiu o książkę Kazimierza Tyszkowskiego o wyprawie Zygmunta III do Szwecji²? VERTE!

W ten dzisiejszy dzień wigilijny jesteśmy czułymi myślami z Państwem i na rok 1966 ślemy Państwu wszystkim moc najserdeczniejszych życzeń Teodor i Ela Parniccy

Mała, składana kartka noworoczna. Na s. 1 widnieje grafika przedstawiająca scenę z życia szlachty dawnej Polski. W środku (wokół nadrukowanych życzeń) oraz na stronicy ostatniej słowa napisane granatowym atramentem przez Parnickiego.

1 Z. Szpotań ski, „I u możnych dziwny...” „Więż” 1965, nr 11.

Zenon Szpotań ski (1919-1976) był krytykiem literackim związanym z „Więzią”.

2 K. Ty s z k ow s ki, Z dziejów wyprawy Zygmunta III do Szwecji w roku 1598. (Relacje i diariusze). Lwów 1927.

15

Warszawa, Miodowa 23 m. 16

14 stycznia 1966

Kochany Panie Jacku,

Nie otrzymałem odpowiedzi na swój ostatni list do Pana (pisałem go na kartce świąteczno-noworocznej), więc w sprawie maszynopisu tomu IV Nowej baśni zwróciłem się wprost do „Więzi” (do pp. Wieczorka ${ }^{1}$ i Krzysztonia); podobno w „Więzi” fragment (ale chyba inny niż wybrany przez Pana) ukaże się w numerze kwietniowym $^{2}$; ma zostać przepisany w ciagu kilku dni i wówczas redakcja odeśle mi maszynopis całości.

Miałbym do Pana jeszcze jedną prośbę: Ossolineum wydało (albo wydaje) ponownie w „Bibliotece Narodowej” Kronikę Galla ${ }^{3}$. W Warszawie tego nie ma w sprzedaży (jeszcze nie ma? już nie ma?!), ale może jest we Wrocławiu. Czy mógłby Pan kupić tam egzemplarz dla mnie? Zdaje się, że przyjeżdża Pan znów w końcu do Warszawy, by mieć z p. Urszulą Kozioł i jeszcze z kimś wieczór autorski w Klubie Domu Książki na rynku Starego Miasta. (Postaramy się z Elą przyjść na ten wieczór autorski). Może by Pan przywiózł mi wówczas Galla (Verte!) 
CD. $z$ odwrotu

gdyby udało się go Panu przed tym terminem we Wrocławiu kupić. Z góry goracco Panu dziękuję.

Równie gorąco dłoń Pańską ściskam - całuję ręce Pani Teresy

Oddany - Teodor Parnicki

List na jednej składanej kartce, zapisanej na stronicach 1, 3 i 4 granatowym atramentem.

$1 \quad$ Wojciech Wieczorek (1928-2012) - socjolog, dziennikarz, od roku 1960 sekretarz redakcji „Więzi”, w latach 1981-1989 redaktor naczelny; od lipca 1989 do połączenia Niemiec był ostatnim polskim ambasadorem w Niemieckiej Republice Demokratycznej, a potem (do r. 1991) kierownikiem berlińskiego przedstawicielstwa Ambasady RP.

2 T. Parnicki, Gliniane dzbany. „Więź” 1966, nr 4.

3 Gall An on im, Kronika polska. Przeł. R. Grodecki. Przekład przejrzał, wstępem i przypisami opatrzył M. Plezia. Wyd. 2. Wrocław 1965. BN I 59. Poprzednie wydanie w serii „BN” ukazało się w roku 1923 w opracowaniu R. Grodeckiego.

\section{Droga Pani Tereso,}

Przypominam sobie, że obchodzi Pani imieniny na Terese „Mniejsza”, czyli 3/X, a nie 15/X, - więc też teraz już ślę wraz z żoną dla Pani moc najserdeczniejszych życzeń ${ }^{1}$

Teodor Parnicki ${ }^{2}$

\section{Drogi Panie Jacku,}

Intensywnie pracuję teraz nad częścią trzecią Twarzy księżyca ${ }^{3}$. Czy dostał Pan już z PAX’u Koła na piasku? Podobno wyszedł już Pański Zagłoba w piekle ${ }^{5}$. Czy mógłby Pan mi to przysłać? Adres mój jest ten sam co dawniej, tylko m. 15, a nie $17^{6}$

\section{Ściskam Pana TP}

Kartka pocztowa ze zdjęciem ruin Monte Albán. Na odwrocie, granatowym atramentem i czerwonym długopisem słowa skreślone przez Parnickiego.

$1 \quad$ Św. Teresa z Ávili (Teresa Wielka) jest wspominana w Kościele katolickim 15 października; św. Teresa z Lisieux (Teresa Mała) - 1 października (wtedy, przed zmianą kalendarza liturgicznego, był to 3 października). Zob. list 32 .

2 Kolorem czerwonym.

3 T. Parnicki, Twarz księżyca. Cz. 3. Warszawa 1967.

4 T. Pa rni cki, Koła na piasku. Powieść z roku 160 przed narodzeniem Chrystusa. Warszawa 1966.

5 J. Łukasiewicz, Zagłoba w piekle. Kraków 1965.

6 Chodzi o przeprowadzkę Parnickiego do innego mieszkania, ograniczającej się w istocie do zmiany lokalu w tym samym budynku.

7 Kolorem czerwonym. 
Drogi Panie Jacku,

Nie odpowiadałem na Pański miły list, czekając na: 1) Zagłobę $w$ piekle; 2) na Pańską recenzję z Kót na piasku w „Tygodniku Powszechnym”, \{Szczególnie ciekaw jestem tej recenzji Pana po zapoznaniu się $\mathrm{z}$ recenzjami Trzebuchowskiego ${ }^{2} \mathrm{w}$ „Za i Przeciw” i Słojewskiego ${ }^{3}$ w „Kulturze” $\}^{5}$ - niestety, ani to, ani tamto dotąd nie nadeszło, - więc dłużej już z listem nie zwlekam, szczególnie iż mam do Pana pewną bardzo konkretną „sprawę” (a raczej: serię spraw).

Niech się Pan nie zdziwi: między 5 a 10 grudnia powinien Pan dostać przekaz pocztowy na 500 zł na moje zlecenie od żony brata Eli, p. Jadwigi Kubińskiej ${ }^{6}$ $z$ Wołomina pod Warszawą. Chodzi o to bowiem, że chcę Pana prosić o przysługę, a raczej znowuż o serię przysług. Mianowicie: zapewne w marcu pojawimy się z Elą znowu w Polsce, a tym razem chyba już na stałe. Otóż na to swoje „nowe życie” już teraz staram się „organizować” swoją prywatną bibliotekę, a że wiem, jak szybko w Polsce książki są rozsprzedawane CD. na odwrocie ${ }^{7}$ / CD. z od w r ot u ${ }^{8}$, zaczynam odczuwać coś w rodzaju paniki, iż książki, na których s z c ze góln ie mi zależy, mogą okazać mi się niedostępne, o ile ni e zostaną kupione na ty chmiast. Sporo zaś $z$ tych książek wychodzi we Wrocławiu, - stąd moja prośba t e ra z właśnie do Pana o kupowanie dla mnie tych książek, \{Oczywiście, książek tych nie należy posyłać do Meksyku, ale niech u Pana czekają na mój ponowny przyjazd do Polskij ${ }^{9}$ - stąd też ten przekaz pieniężny na opłacanie tych zakupów.

A więc najpierw książki z „Biblioteki Narodowej” (Ossolineum, wł a ś n i e Wrocław), - mianowicie: St aff Wybór poezji ${ }^{10} \mathrm{w}$ opracowaniu Jastruna. J a n a K och a n ow sk i g go Psałterz Dawidów ${ }^{11}$ w opracowaniu Ziomka. A ri o s to Orland Szalony w przekładzie Piotra Kochanowskiego ${ }^{12}$. Stanisław Herakliusz Lu b o m ir ski Wybór dziet ${ }^{13}$. Ra di s z c zew Podróż z Petersburga do Moskwy ${ }^{14}$. Dalej: a n ty kw a ry c zn i e, oczywiście, bo i jakże inaczej? Stara monografia (całość, możliwie) Kleinera o Słowackim ${ }^{15}$.

Wreszcie sam Słowacki (we Wrocławiu właśnie, zdaje się, b a r d z o wciąż nad nim się pracuje:) - chodzi mi naprawde o trzy dzieła: Beniowski (w układzie Kleinera), (Może antykwarycznie też dałby się odnaleźć Beniowski w opracowaniu Kleinera tejże „Bibl[ioteki] Narod[owej]” z tegoż O s s olin e u m, ale przedwojennego (lwowskiego)? $\}^{16}$ Król-Duch oraz dramat (fragmenty, ale wszystki e fragmenty) Samuel Zborowskit ${ }^{17}$.

W sprawie Słowackiego może Pan miałby jakieś własne sugestie? ${ }^{18}$ (może kupić c ał o ś ć krytycznego wydania bodajże pod redakcją Floriana [!]? $\left.{ }^{19}\right)$ Zapewne trzeba byłoby na to więcej jeszcze pieniędzy. Ile? Dostałbym! \{CD. na marginesie na odwrocie $^{20} /$ CD. $z$ marginesu na odwrocie ${ }^{21}$ Poza tym proszę nieustannie polować na przedwojenne („Rój”, 1937) wydanie Aecjusza ${ }^{22}$; za to proszę zapłacić, ile zażądają. Przepraszam Pana za kłopot. $Z$ góry gorąco dziękuję. Przed świętami chyba raz jeszcze do Pana napiszę. Ściskam. Teodor $\mathrm{P}^{23}{ }^{24}$ \{Czy dostał Pan już na moje zlecenie z PIW'u tom IV Nowej baśni?\} ${ }^{25}$ 
1 J. Łuk k siewi cz, Teodor Parnicki: „Koła na piasku”. „Tygodnik Powszechny” 1967, nr 1, s. 6. Przedruk w: Republika mieszańców (1974).

2 Paweł Trzebuchowski - krytyk literacki, związany m.in. z „Za i Przeciw”. Zob. P. Trzebuch ow s ki, Czyżby zmierzch? „Za i Przeciw” 1966, nr 41, s. 13, 15.

3 Jan Zbigniew Słojewski (ur. 1934) - krytyk literacki i felietonista. Ukończył polonistykę na Uniwersytecie Warszawskim, związany m.in. ze „Współczesnością” (należał także do Grupy Literackiej Współczesność) i z „Kulturą”. Zob. Z. Słoj e w s ki, Mieszaniec, polityka i sny. „Kultura” 1966, nr 44, s. 3.

4 Chodzi tu o „Kulturę” tzw. warszawską - czasopismo kulturalno-społeczne ukazujące się w latach 1963-1981.

5 Tekst zapisany na marginesie s. 1.

6 Jadwiga Ku bińs k a - żona brata Eleonory Parnickiej, Wojciecha Kubińskiego.

Kolorem czerwonym.

Kolorem czerwonym.

Tekst zapisany na marginesie s. 2.

L. Staff, Wybór poezji. Wybór, wstęp M. Jastrun. Przypisy M. Bojarska. Wrocław 1963. BN I 181.

11 J. Ko ch a now ski, Psałterz Dawidów. Oprac. J. Zi o mek. Wrocław 1960. BN I 174.

12 L. Ariosto, Orland Szalony. Przeł. P. Kochanowski. Oprac. R. Pollak. Wrocław 1965. BN II 150.

13 S. H. Lubomirski, Wybór pism. Oprac. R. Pollak. Wrocław 1953. BN I 45.

14 A. Radis zc ze w, Podróż z Petersburga do Moskwy. Przeł. S. Pollak. Oprac. W. J a ku b ow ski. Wrocław 1954. BN II 87.

15 J. Kle in er, Juliusz Stowacki. Dzieje twórczości. T. 1-4. Wyd. 3. Lwów 1919-1927. Pomijając wydania przedwojenne - wznowienie całości ukazało się dopiero w roku 1999 w Wydawnictwie Literackim.

16 Tekst zapisany na marginesie s. 2.

17 Chodzi najprawdopodobniej o wydanie Dziet wszystkich pod redakcją J. Kle in era. Przed wojną ukazywały się one w latach 1924-1933 (11 tomów), a następnie pod redakcją Kleinera i W. Floryana w latach 1952-1976 (17 tomów). Beniowski został wydrukowany jeszcze przed wojną, Król-Duch również, ale tylko pierwszy rapsod, reszta zaś - podobnie jak Samuel Zborowski - już w drugiej, obszerniejszej edycji. Zob. listy 20, 26, 48.

18 Kolorem czerwonym.

19 Parnicki miał na myśli najpewniej wspomniane tu już wydanie, tyle że po śmierci Kleinera (1957) edycję kontynuował właśnie Floryan.

20 Kolorem czerwonym.

21 Kolorem czerwonym.

22 T. Parnicki, Aecjusz, ostatni Rzymianin. Powieść historyczno-biograficzna. Warszawa 1937.

23 Kolorem czerwonym.

24 Tekst zapisany na marginesie s. 2, następnie na marginesie s. 1.

25 Tekst zapisany u góry s. 1, najpewniej pełni funkcję postscriptum.

Drogi Panie Jacku,

Nie dostałem odpowiedzi Pana na swój list z 22 listopada. Ale spodziewam się, że ów mój list dostał Pan, więc nie były dla Pana zaskoczeniem 500 zł, które bratowa Eli (jak mi pisała) przekazała Panu 6 grudnia. Czekam z dużą niecierpliwością na Pańskie sugestie w sprawie zakupu Słowackiego dla mnie. Na razie zaś - gdy chodzi o mnie samego - prosiłbym Pana o rozejrzenie się za jedna jeszcze pozycją, a to chyba antykwaryczną też \{Aha, i jeszcze coś! W-two KUL’u: „Roczniki 
Teologiczno-Kanoniczne", tom XIII, zeszyt I ${ }^{1}$ (Pismo Święte) chyba ś w i e ż o wydane... $\}^{2}$ (bo o innej chyba marzyć nie sposób): Kronika Dytmara w opracowaniu M. Jedlickiego $o^{3}$ (chyba wydanie Instytutu Zachodniego w Poznaniu ${ }^{4}$, a to Z r. 1953 albo 1954).

Natomiast miałbym do Pana dwie prośby „extra” specjalne: mam w Meksyku przyjaciół, którym dość dużo zawdzięczam, a którym przed laty robiłem - przez lata też - upominki noworoczne w postaci kolejnych tomów (i poszczególnych części tych tomów) Historii Polski, w-twa Polskiej Akademii Nauk ${ }^{5}$. Doszedłem do zamknięcia (częścią 3 z r. 1959 i częścią 4 z r. 1960) tomu II. Ale ukazały się pewnie kontynuacje. Otóż czy byłby Pan łaskaw kupić w s zy s t k i e kontynuacje, jakie dotąd się ukazały, i wysłać je pocztą pole c on ą, ale nie lotniczą pod adresem: Señora Nina Galewicz ${ }^{6}$, Saratoga, 140 Coloma Lomas-Hipódromo M é x i c o D. F. (Zona 10) México - Meksyk.

Druga sprawa podobna: zauważył Pan chyba dedykację I u możnych dziwny: Andrzejowi Madeyskiemu? Otóż zależy mi ogromnie na tym, by Andrzej M[adeyski] miał Zagłobę $w$ piekle. Proszę kupić tę książkę w księgarni za pełną c en ę katalogową \{stanowczo\} $\}^{7}$ - i dołączyć do niej świeżo wydaną przez PIW książeczkę (chyba o to w księgarniach nietrudno) Stanisława Żółkiewskiego, hetmana, Poczatek i progres wojny moskiewskiej - posłać (też poczta p ol e c on ą, ale n i e lotnicza): Monsieur Andrzej Madeyski, 4960, Coronet - Apt. 6. Montre al, 26 (P. Q.) Canada - Kanada. $Z$ góry gorąco dziękuję. Przepraszam serdecznie za kłopot.

To jednak zdumiewające, że Pan wyczuł (lecz: czy istotnie wyczuł? może po prostu: intelektem przeniknął?) moje opory, gdy chodzi o rozstanie się z Leptynesem, więc też moje „ciagoty” do powieści o upadku Eutydemidów. W Polsce (utwierdził mnie w tym przekonaniu Pański Powrót do eposu w Zagł[obie] $w$ piekl[e ${ }^{9}$ ) jest tylko dwu ludzi, zdaniem moim, którzy ze mną w pełn i współdziałają myślowo (chciałoby się rzec dwuzna c zn i e: współ-czują myślowo!), ale z tych dwu tylko jeden mówi na głos o tym..., j e st to $\mathrm{P}$ a n..., drugiemu jak gdyby różne uboczne względy nakazywały ciagge... niedopowiadanie... (prosząc Pana gorąco o be zw z gl lę dną dyskre cję, wymienię drugiego: Wacław Sadkowski ${ }^{10}$ )... Ale teraz (proszę mi darować prawdopodobny nietakt...) czy i Panu się nie przydarzył moment świadomego „niedopowiedzenia”?... Mam na myśli cytat na Pańskiej stronie 228. - Przecież w moim tekście to nie jest o Krzyżakach mowa, ale o polskich rycerzach pod Grunwaldem ${ }^{11} \ldots$

Jeszcze coś o Zagł[obie] w piekle. I ja też od blisko 45 lat zżymam się wciąż na Wyspiańskiego, ale Pan okazuje się być dlań nieporównanie surowszy ode mnie... Dla mnie „sprawiedliwy w Sodomie” ${ }^{12}$ wśród pomysłów Wyspiańskiego jest... biskup Stanisław - nie z Bollesława] Śm[iałego], ale z Na skałce ${ }^{13}$... z III aktu..., gdy śmierć mu służy jako ministrant... i gdy w świat dziwożon, lelów, poświstów etc., etc. wdziera się nagle powiew innego świata (jak gdyby mutatis mutandis ${ }^{14}$ świata ze St[owa] i ciała czy Sr[ebrnych] ort[ów] \{takie porównanie to chyba szczyt „zarozumiałości”... bo Wysp[iański] to był bezspornie wielkiej miary geniusz... Ale przecież zawsze szukamy materiału do porównań w tym (lub z tym), co nasze własne.... $\}^{15}$ w replice, zaczynającej się od słów: „Otworzę Księgi Rodzaju...”16

Ściskam Pana gorąco - Teodor Parnicki ${ }^{17}$

\{PS. ${ }^{18}$ Pisał do mnie Cieślikowski, że zabiega około wystawienia przez Skuszankę 
Końca „Zg[ody] Nar[odów]”... (Czemu nie Tylko Beatr[ycze] raczej?) Jestże to realne, wedle Pana? W arcyuroczym Sław[omirze] Cieśl[ikowskim] ${ }^{19}$ chyba jest sporo $z$ fantasty...20 21

\{PS. II ${ }^{22}$ - Czy dostał Pan z PIWu tom IV Now[ej] baśni? PAX ma przesłać Panu Śmierć Aec[jusza $\left.{ }^{23}.\right\}^{24}$

\{Powtarzam: książki, dla mnie samego kupowane, mają u Pana czekać na mój ponowny przyjazd do Polski. $\}^{25}$

List na dwóch kartach, zapisanych obustronnie granatowym atramentem i czerwonym flamastrem. W rogu drugiej karty (s. 3) pojawia się arabska dwójka.

1 „Roczniki Teologiczno-Kanoniczne” 1966, z. 1. Pod tym tytułem ukazywały się one w latach 1949-1993 (później jako „Roczniki Teologiczne”), wydawane były przez Katolicki Uniwersytet Lubelski.

2 Tekst zapisany na marginesie s. 1.

3 Kronika Thietmara. Przeł., wstęp, komentarze M. Z. J edlicki. Poznań 1953.

4 Instytut Zachodni w Poznaniu - Instytut Naukowo-Badawczy im. Zygmunta Wojciechowskiego, założony przez Ministerstwo Spraw Zagranicznych w 1944 roku. Zajmuje się interdyscyplinarnymi badaniami nad stosunkami międzynarodowymi, zwłaszcza polsko-niemieckimi.

5 Najprawdopodobniej chodzi o wydawnictwo PWN i o Historię Polski. Opracowanie zbiorowe (t. 1-4. Warszawa 1955-1978). Tom 1 (Do roku 1764) ukazał się w trzech częściach, tom 2 (1764-1864) w czterech, tom 3 (1850/1864-1918) znów w trzech, a tom 4 (1918-1939) w czterech częściach. Nina Galewi c z - żona Jana Ga lew i c za, konsula PRL w Nowym Jorku w latach 1949-1953. Małżonkowie potem osiedli w Meksyku, gdzie Jan był przedsiębiorcą. Bliscy przyjaciele Parnickich. Słowo zapisane na marginesie s. 2.

8 S. Żółki ews ki, Początek i progres wojny moskiewskiej. Oprac. J. Ma cis z e ws ki. Warszawa 1966.

9 J. Łuka si e wi c z, Ucieczka od „eposu”. W: Zagłoba w piekle. Kraków 1965.

10 Wacław Sadk ow s ki, pseudonim Wacław Rola (ur. 1933) - krytyk, eseista, tłumacz. Ukończył polonistykę na Uniwersytecie Warszawskim. Przed rokiem 1952 publikował m.in. w czasopismach „Dziś i Jutro” i „Tygodniku Powszechnym”. W latach 1972-1993 redaktor naczelny „Literatury na Świecie”, współpracował z „Życiem Warszawy” i „Współczesnością”. Był mocno związany z linią PZPR. Zob. W. S a d k ow s ki, Parnicki. Wprowadzenie w twórczość powieściopisarska. Warszawa 1970.

11 Zob. Łuka s i ew i c z, Ucieczka od „eposu”, s. 227-228: „W drugim tomie Nowej baśni jest mowa o Kościele Piotrowym, do którego należą ubodzy i "maluczcy", i o kościele Józefińskim (pochodzącym mniemanie od Józefa z Arymatei), który skupia "możnych", pragnących zachować "obyczaj ojców". Pierwsi posługiwali się środkami "ubogimi", drudzy "bogatymi»; pierwsi przekonywali, drudzy zaś to byli Krzyżacy [...]”.

12 Określenie pochodzące $z$ Biblii. Ostatnim sprawiedliwym miał być Lot, uratowany z Sodomy przez Aniołów (Rdz 18-19).

13 Chodzi o dramat Skałka (w: S. Wy s piańs ki, Bolesław Śmiały. - Skałka. Oprac. J. N ow ak o w s ki. Wrocław 1969, s. 160. BN I 198). Ważne są też słowa Biskupa wypowiedziane do Śmierci: „Ciałem się słowo stało”.

Mutatis mutandis (łac.) - dokonawszy niezbędnych zmian.

Tekst zapisany na marginesach s. 4.

U Wy s piań s ki e go (op. cit., s. 166) Biskup mówi:

Otworzysz pismo rodzaju, bym widział stróże ołtarza, mocarze mojego kraju, jak Duch je Boży pomnaża.

Kolorem czerwonym.

Kolorem czerwonym. 
w trakcie drugiej wojny światowej i opozycji w czasach PRL; pomysłodawca założenia Towarzystwa Literackiego im. Teodora Parnickiego. Mąż profesor Teresy C i eśl i k o w s k i e j, z domu Skibniewskiej (ur. 1926) - teoretyk literatury, profesor Uniwersytetu Łódzkiego, autorki monografii Pisarstwo Teodora Parnickiego (Warszawa 1965) oraz artykułów o twórczości Parnickiego.

Do realizacji tego pomysłu nie doszło. Trudno zresztą ocenić stopień jego realności. Jedyną sztuką teatralną Parnickiego było Mandżukuo. (Walka o Wschód), wystawione w Teatrze Popularnym w Łodzi w 1934 roku.

21 Tekst zapisany na marginesie s. 2.

22 Kolorem czerwonym.

23 T. Parni cki, Śmierć Aecjusza. Powieść z lat 451-457. Warszawa 1966.

24 Tekst zapisany na marginesie s. 1.

Tekst zapisany u góry s. 1, nie przyporządkowany do określonego miejsca w treści listu.

[grudzień 1966]

Wielce Szanownym i Drogim Państwu Teresie i Jackowi Łukasiewiczom ${ }^{1}$ \{a za łaskawym pośrednictwem Państwa także i pani Urszuli Kozioł z mężem i z bratem\} ${ }^{2}$ - wraz z synem i z Panią Gosposią - najmilszych świąt oraz najszczęśliwszego roku 1967 życzą E. i T. Parniccy ${ }^{3}$

Mała, składana kartka pocztowa. Na s. 1 widnieje grafika przedstawiająca zajączka. W środku, po obu stronach, pisał Parnicki czerwonym flamastrem i granatowym atramentem.

1 Kolorem czerwonym.

2 Tekst zapisany po lewej stronie kartki.

3 Kolorem czerwonym.

Drogi Panie Jacku,

Śpieszę Pana powiadomić, że zapewniłem sobie na półkuli zachodniej Beniowskiego w wydaniu Kleinera ${ }^{1}$ oraz pierwsze (z roku 1937) wydanie Aecjusza. Na komplet dzieł Słowackiego w wydaniu Krzyżanowskiego ${ }^{2}$ nie reflektowałbym; natomiast prosiłbym Pana o zapewnienie mi i tego wydania prozy Słowackiego, o którym Pan wspominał ${ }^{3}$, i - w jakimkolwiek bądź wydaniu (najlepiej - jasna rzecz - w wydaniu pod redakcją Kleinera) Lilli Wenedy, i Księcia Niezłomnego. Na Króla-Ducha, owszem - tak jak właśnie Pan to sugerował - czekajmy, aż się ukaże w tym samym wydaniu, co Samuel Zborowski, którego już był Pan łaskaw kupić dla mnie ${ }^{4}$.

Prosiłbym też Pana o nabycie po cenie katalog o w ej dalszych dwu egzemplarzy Zagłoby $w$ piekle CD. na odwrocie ${ }^{5}$ / CD. z od w r ot u $\mathbf{u}^{6}$ i o spowodowanie, \{Może dla Pana jest kłopotliwe osobiste kupowanie i wysyłanie własnej książki? Ale w takim razie chyba mogłaby tym się zająć administracja czy to „Znaku”, czy „Więzi", a Pan by im tylko przesłał pieniądze za książkę i przesyłkę oraz adresy... $\}^{7}$ iżby zostały wysłane pod adresami:

1) Doctor Wiktor Weintraub, 383. Broadway, Ca mbridge, 39, Mass. U.S.A. Stany Zjednoczone. 
2) Doctor Konstantin Symmons ${ }^{8}$, 160. E. Pennsylvania Avenue J a c k s o n ville, Illinois. U.S.A. - Stany Zjednoczone.

Oczywiście, zakładam, że na wszelkie zakupy książek dotychczasowe, jak dalsze, może nie wystarczyć pieniędzy, które już Pan na moje zlecenie dostał, więc zapewne w końcu lutego szwagierka moja, Jadwiga Kubińska, przekaże Panu znów jakąś kwotę: może 200, może $300 \mathrm{zl}$.

Czy udało się Panu dostać Wybór pism Herakliusza Stanisława Lubomirskiego w wydaniu „Bibl[ioteki] Narod[owej]” - Ossolineum? Bardzo o to prosiłbym, choćby i o egzemplarz tzw. „Z drugiej czy trzeciej ręki”. Prosiłbym także o Pana Tadeusza \{w tymże wydaniu (opracowanie - o ile się nie mylę - Pigonia) ${ }^{9}$. A co do Staffa, może a n ty k w a ry c z n i e byłoby do nabycia kompletne (chyba 7 -tomowe) wydanie sprzed lat bodajże 7 czy 8? Reflektowałbym na to. Za wszystko gorąco Panu dziękuję. Równie gorąco dłoń Pańską ściskam - Teodor Parnicki ${ }^{10}{ }^{11}$ \{PS. ${ }^{12}$ Pisał mi Henryk Bereza ${ }^{13}$, że to Pan ma recenzować w „Twórczości” tom IV Nowej baśni. Ogromnie mnie ta wiadomość ucieszyła, rzecz jasna. Ale coś mnie też b[ardzo] zaciekawiło: $z$ listu Berezy wynika, że to on teraz kieruje działem krytyki w „Twórczości”. Przedtem kierował Kijowski. Czy więc należałoby rozumieć, że Kijowski w ogóle $\mathrm{z}$ „Twórczości” odszedł, - czy też zerwał z nią?! $\left.{ }^{14}\right\}^{15}$

List na jednej karcie, zapisanej obustronnie granatowym atramentem i czerwonym flamastrem.

J. Słow a cki, Dzieła. Red. J. Krzyża now ski. Wrocław 1949. W późniejszych latach ukazywały się nowsze wydania.

3 Być może, chodzi o Pisma proza opracowane przez W. Flory a na. Stanowiły one tom 10 Dziet w edycji Krzyżanowskiego. Kolejne wydania ukazały się w latach 1952 i 1959.

4 Zob. list 17. Chodzi o Dzieła wszystkie pod redakcją J. Kl e in e ra. Lilla Weneda ukazała się w tomie 4 z roku 1953, Ksiażę Niezłomny w tomie 7 (1956), Samuel Zborowski w tomie 13 (1963). Na Króla-Ducha, poza pierwszym rapsodem, będzie musiał Parnicki poczekać do roku 1972 (t. 16) i 1975 (t. 17) - zob. listy 26, 48.

Kolorem czerwonym.

Kolorem czerwonym.

Tekst zapisany na marginesie s. 2 .

Konstanty Symmons-Symonolewicz - socjolog, profesor Allegheny College. Przyjaciel Parnickiego z gimnazjum w Harbinie i syn jego mentora, Konstantego Symonolewicza. Do USA wyjechał przed wybuchem drugiej wojny światowej.

A. Mi cki ew ic z, Pan Tadeusz, czyli Ostatni zajazd na Litwie. Historia szlachecka z roku 1811 i 1812 we dwunastu księgach wierszem. Oprac. S. Pi goń. Wyd. 5. Wrocław 1967. BN I 83.

Kolorem czerwonym.

Tekst zapisany na marginesie s. 2.

Kolorem czerwonym

Henryk B ere za był w tym okresie redaktorem czasopisma „Twórczość”.

Bereza objął dział krytyki w „Twórczości” w roku 1966 i prowadził go do 1978 roku.

Tekst zapisany na marginesie s. 1. 
Drogi Panie Jacku,

Od soboty 1 lipca jesteśmy w Polsce; od 3 lipca - w Warszawie.

W piątek 7 lipca tknęła mnie przykra rzecz: porażenie błędnika. Chyba nigdy dotąd w życiu nie czułem się (na szczęście przez pół dnia tylko) aż tak źle.

Dzwoniłem do „Więzi”; ni e oczekują Pana wkrótce w Warszawie. Szkoda!

Co do ksiazżek, - chyba Jadzia Kubińska w całości już zwróciła Panu należność; jeżeli ni e, proszę dać mi znać.

Mieszkamy: ul. Zim or ow ic za $2 \mathrm{~m}$. 1010 . Jest to boczna Filtrowej; idac od pl. Narutowicza, mija się Raszyńską, i chyba drugą (lub trzecią) po Raszyńskiej jest właśnie ulica Zimorowicza. - Ściskam Pana gorąco - Teodor P.

List na jednej karcie, zapisanej obustronnie niebieskim atramentem.

1 To adres, pod którym Parnicki mieszkał po przeprowadzce do Warszawy, aż do śmierci w 1988 roku.

Drogi Panie Jacku,

Spodziewam się, że już wrócił Pan z urlopu. Ze zdrowiem moim, niestety, nie jest najlepiej; zmysły i równowagi, i słuchu sprawiają mi coraz to większe kłopoty...

Nie wiem \{raczej: nie pamiętam\} $\}^{1}$, czy dałem Panu znać już, że na Verte! / CD. z odwrotu ${ }^{3}$ Atlantyku skończyłem pracę nad tomem piątym Nowej baśni ${ }^{4}$. Ma być jeszcze tom szósty...

Żałuję bardzo, iż szybko Pana nie zobaczę.

Proszę Pana o jeszcze tr zy książki $z$ „Biblioteki Narodowej”, Wrocław. 1) Senek a Fedra ${ }^{5}$. 2) Antologia listu antycznego ${ }^{6}$. 3) Go ethe Ifigenia $w$ Taurydzie $^{7}$.

$Z$ góry gorąco Panu dziękuje

\section{Ściskam, - oddany Teodor Parnicki ${ }^{8}$}

List na jednej małej kartce, zapisanej obustronnie niebieskim i czerwonym atramentem.

Tekst zapisany na marginesie s. 1.

Kolorem czerwonym.

Kolorem czerwonym.

T. Parnicki, Nowa baśń. Cz. 5: Wylęgarnie dziwów. Warszawa 1968. Postscriptum autora do powieści: „Praca nad powieścią Wyleggarnie dziwów dokonywała się częściowo (gdy nad innymi tomami Nowej baśni w całości) w mieście Meksyku, a częściowo na statku PLO "Polanica" - w drodze z Meksyku do Polski. Dobiegła końca 18 czerwca 1967 roku na Oceanie Atlantyckim, mianowicie w punkcie przecięcia się równoleżnika $34^{\circ} 01.4^{\prime}$ szerokości północnej i południka $75^{\circ} 37.7^{\prime}$ długości zachodniej” (s. 5).

5 Se neka, Fedra. Przeł. A. Świ derkówna. Oprac. W. Strzelecki. Wrocław 1959. BN II 118.

6 Antologia listu antycznego. Oprac. J. Schnayd er. Przeł. J. Czubek [i in.]. Wrocław 1959. BN II 117.

7 J. W. Go eth e, Ifigenia w Taurydzie. Przeł., oprac. E. C s a tó. Wrocław 1965. BN II 149.

8 Kolorem czerwonym. 
Drogi Panie Jacku,

W nawiązaniu do listu sprzed dwu dni śpieszę Panu donieść, że już sam w Warszawie kupiłem Ifigenię $w$ Taurydzie G o e th e go i Antologię listu antycznego, więc ty ch dwu książek proszę już ni e kupować. CD. na odwrocie ${ }^{1} /$ CD. z odwrotu ${ }^{2}$ $\mathrm{O}$ ile jednak już je Pan kupił, może by księgarnia Ossolineum zamieniła je Panu na coś, np. na Tlytusa] Li wi u s z a ${ }^{3}$ lub Ta c y ta ${ }^{4}$ w tejże „Bibliotece Narodowej”? Jeżeli ni e wymienią, to, rzecz jasna, proszę dostarczyć mi także i Ifigenię, i Antologię i włączyć w rozliczenie.

\section{Z góry gorąco dziękuję. Ściskam mocno, - Teodor Parnicki ${ }^{5}$}

List na jednej małej kartce, zapisanej obustronnie niebieskim i czerwonym atramentem.

$1 \quad$ Kolorem czerwonym.

2 Kolorem czerwonym.

3 Tytus Liwiusz, Dzieje od założenia miasta Rzymu. (Wybór). Przeł., oprac. W. Strzelecki. Wrocław 1953. BN II 77. Wydanie 2, poszerzone, ukazało się w 1955 roku.

4 Ta cy t, Wybór pism. Przeł., oprac. S. H a m m e r. Wrocław 1953. BN II 82. Wydanie 2, zmienione, ukazało się w 1956 roku.

5 Kolorem czerwonym.

Drogi Panie Jacku,

Dziękuję Panu serdecznie za list, za paczkę z książkami i przekaz pieniężny (wszystko przyszło w tym samym dniu). Cieszę się ogromnie na myśl, że zobaczę Pana. Telefon mój jest: 25-48-35.

Dłoń Pańską ściskam gorąco. Pani Teresie ręce całuję oddany

Teodor Parnicki

List na jednej karcie, zapisanej jednostronnie czarnym atramentem.

Drogi Panie Jacku,

Spodziewam się, że mile spędzają Państwo Święta. Na rok 1968 ślemy moc najserdeczniejszych Życzeń

Ela i Teodor Parniccy

List na jednej małej kartce, zapisanej jednostronnie niebieskim atramentem. 
Drogi Panie Jacku,

Byłbym Panu ogromnie zobowiązany za wiadomość, czy znany Panu jest tekst rozmowy ze mną p. Krystyny Nastulanki ${ }^{1}$ w tygodniku „Polityka” $z 2$ albo $3 \mathrm{marca}^{3}$ ?

Poza tym mam do Pana dwie gorące prośby: 1) wśród książek, które Pan łaskawie dla mnie ma sow o kupował, był tom zawierający rapsod pierws zy Króla-Ducha. Czy mógłby Pan stwierdzić, czy w tym samym wydaniu Ossolineum wrocławskiego ukazał się j uż tom obejmujacy re sz tę tekstu Króla-Ducha ${ }^{4}$ ? O ile tak, proszę kupić ten tom i wysłać go do mnie; należność zwróciłbym Panu natychmiast.

2) Proszę odszukać w książce telefonicznej Wrocławia Jadwigę Szajn a - Lew a n d o w s k ą (albo Lewandowską-Szajna, ale to mniej prawdopodobne) i przysłać mi jej adres (zdaje się: ulica Okrzei, ale nie pamiętam numerów domu i mieszkania).

$Z$ góry go rac co Panu dziękuję.

Dłoń Pańską ściskam serdecznie, całuję ręce Pani Teresy Oddany Teodor Parnicki ${ }^{5}$

\{PS. ${ }^{6} \mathrm{~W}$ wi el ka n o c ny m numerze „Kierunków” ma się ukazać fragment z „Zabij Kleopatre" 7 . Cieszyłbym się, gdyby Pan to przeczytał.

T. P. 8$\}^{9}$

\{PS. II ${ }^{10}$ Bardzo mnie wzruszyły Pańskie uwagi o znaczeniu moich książek dla Pana - w numerze ,jubileuszu” „Więzi”"11.\}12

List na dwóch kartach, zapisanych jednostronnie niebieskim i czerwonym atramentem. W lewym górnym rogu s. 1 widnieje niezidentyfikowany dopisek i data 7 IV (jest to najprawdopodobniej data wysłania listu). W prawym górnym rogu s. 2 znajduje się rzymska dwójka.

Krystyna Na st u la n ka (1921-1999) - dziennikarka, scenarzystka filmowa.

2 Warto tu nadmienić, że w roku 1993 Parnicki został (pośmiertnie) laureatem pierwszej edycji „Paszportów Polityki” w dziedzinie literatury.

3 K. N a stu la n ka, Rozmowa z Teodorem Parnickim. „Polityka” 1968, nr 9.

4 Zob. listy 17, 20, 48. Pozostałe, poza pierwszym, rapsody Króla-Ducha w edycji Klein er a i Flory a na ukazały się w t. 16-17 (lata 1972-1975).

Kolorem czerwonym.

Kolorem czerwonym.

T. Parnicki, „Zabij Kleopatre”. „Kierunki” 1968, nr 15.

Tekst zapisany na marginesie s. 2.

Kolorem czerwonym.

Kolorem czerwonym.

Najprawdopodobniej chodzi o artykuł J. Łuka si ew i c za Ćwiczenia miesięczne. Ćwiczenia na jubileusz („Więź” 1968, nr 2). Czytamy tam: „W tych dniach jubileuszu pierwszy Twój numer [tj. „Więzi”] kojarzy mi się z twórczością Teodora Parnickiego. Jego powieści wtedy właśnie zaczynałem odkrywać, jego przygodę pisarską przeżywać. [...] Dzięki Tobie również uległem na długie dziesięć lat magii tych powieści, męczących i pociagających, wielkich i nie kończaccych się. W nich podjęta została próba ukazania, wyobrażenia łączności ludzkości, dramat tego wyobrażenia” (s. 180). 
Drogi Panie Jacku!

\{Bardzo bym się cieszył, gdyby i z nagłówków listów Pana do mnie znikły słowa „Wielce Szanowny”. $\}^{1}$

Dziękuję serdecznie za list. Ciekawym, czy ktoś kiedyś wytknie mi ustęp „o mieszańcach"w rozmowie z Nastulanką ${ }^{2}$ (t o o n a, zreszta, naciskała na mnie, bym w tej sprawie wypowiedział się), jako objaw „kosmopolityzmu”...

Mam do Pana prośbę: aby Pan w świątecznym numerze CD. na odwrocie $^{3} /$ CD. z odwrotu ${ }^{4}$ „Kierunków” przeczytał fragment mojej powieści „Zabij Kleopatrę".

Sygnalizował mi Krzysztoń „rozprawienie się” Szpotańskiego w numerze „Więzi" chyba czerwcowym $z$ moim podejściem do historii (uwagi na marginesie części III Twarzy księżyca) ${ }^{5}$. Bardzo jestem ciekaw tego; ze Szpotańskim (z pp. Eska, jako $\mathrm{z}$ „chórem ateńsko-tragicznym”) miałem interesujące „starcie się” jeszcze na początku roku 1964.

Spodziewam się, że będą Państwo mieli ${ }^{6}$ \{miłe święta wielkanocne. Ślemy z Elą dla Państwa wszystkich moc serdeczności. Teodor Parnicki\} ${ }^{7}$

List na jednej karcie, zapisanej obustronnie granatowym i czerwonym atramentem.

1 Tekst zapisany na marginesie s. 1.

2 Zob. K. Na stula nka, Rozmowa z Teodorem Parnickim. „Polityka” 1968, nr 9, s. 7: „Otóż mieszaniec czując, że nie uznaje go w pełni za swojego ani społeczność ojca, ani matki, dąży do tworzenia idei, które by mogły się stać podstawą dla jakiejś nowej społeczności. Wydaje mi się, że jest to proces dokładnie dialektyczny: ojciec i jego społeczność to jest teza, matka i jej społeczność antyteza, a mieszaniec zdąża do stworzenia syntezy. Za klasyczny przykład dziejowy społeczności mieszańców uważam chrześcijaństwo - tezą byłaby teologia judaizmu, antytezą - kultura i filozofia grecko-rzymska. [...] Można tę samą sprawę postawić nieco inaczej: szara kaczka prześladowana zarówno przez białe, jak i czarne, wynajduje sobie właśnie sposoby ratowania się (w świecie ludzkim wynajduje idee) niedostępne ani czarnym, ani białym”.

3 Kolorem czerwonym.

4 Kolorem czerwonym.

5 Z. Sz p o tan s k i, Teodora Parnickiego „Twarz księżyca”. „Więź” 1969, nr 1.

6 Kolorem czerwonym.

7 Tekst zapisany na marginesie s. 2 kolorem czerwonym.

Drogi Panie Jacku!

Wysłałem do Pana dzisiaj, jako „druk polecony” - tom piąty Nowej baśni. Spodziewam się, że nie jest Pan na urlopie, a co najmniej już, że ktoś w mieszkaniu Państwa będzie $\mathrm{w}$ chwili, gdy tę paczkę $\mathrm{z}$ poczty przyniosą.

Spodziewam się, że nie weźmie mi Pan za złe zużytkowania d r u gi e g o z Pańskich nazwisk ${ }^{1} \mathrm{w}$ tym tomie piątym. 
Wydaje mi się, że „najciekawiej” byłoby, gdyby właśnie Pan i właśnie to m p i ą ty (ze szczególnym naciskiem na Księgę nową o misce soczewicy²) mógł i chciał omówić krytycznie czy to w „Tygodniku Powszechnym”, czy w „Znaku”.

Ściskam Pana serdecznie

\section{Teodor Parnicki ${ }^{3}$}

\{PS. Nie jest dobrze z moim zdrowiem (ogłuchłem w $90 \%$ na lew e ucho - dużo w tym mojej „winy”: nadmiar papierosów!! $\left.{ }^{4}\right\}^{5}$

List na jednej karcie złożonej na pół, zapisanej na s. 1 i 3 (postscriptum znajduje się na s. 2) niebieskim i czerwonym atramentem.

1 Chodzi o nazwisko Petelenz - pierwszy człon nazwiska adresata listu (zob. list 29).

2 Część pierwsza piątego tomu Nowej baśni nosi tytuł Księga nowa o misce soczewicy, czyli „Baśn nad baśniami”.

3 Kolorem czerwonym.

4 Być może, nadmiar papierosów spowodował zwężenie tętnicy błędnika i w efekcie problemy ze słuchem.

$5 \quad$ Tekst zapisany kolorem czerwonym po lewej stronie kartki złożonej na pół.

Drogi Panie Jacku!

Na początku lipca (chyba 8-go) wysłałem Panu jako „Druk polecony” tom piat ty Nowej baśni. Czy pan to dostał? \{Małgorzacie Czermińskiej ${ }^{1}$ do Gdańska posłałem ten sam tom tego samego dnia; w kilka dni później otrzymałem od niej wiadomość, że dostała. $\}^{2}$ Może milczenie Pana tłumaczyć należy wyjazdem w s z y s t k i c h Państwa na urlop? Mam nadzieję, że nie musiałbym go tłumaczyć sobie w sposób, który by przyprawił mnie o poczucie winy: mianowicie, że czuje Pan do mnie urazę za posłużenie się w tomie tym także i nazwiskiem PETELENZ bez uprzedniego uzyskania zgody Pana? Gdyby tak było, przepraszam najmocniej; jednakże (niech mi Pan wierzy) kierowała w tym mną tylko przyjaźń do Pana: chciałem mieć w tekście nazwisko to w pobliżu nazwiska PARZNICKI

\{Ściskam dłoń Pańską gorąco - Teodor Parnicki $\}^{3}$

List na jednej karcie złożonej w pół, zapisanej na s. 1 i 3 granatowym i czerwonym atramentem.

$1 \quad$ Małgorzata C z e r m iń s k a jest autorką m.in. książek Czas w powieściach Parnickiego (Wrocław 1972) oraz Teodor Parnicki (Warszawa 1974).

2 Tekst zapisany na marginesie s. 1.

3 Kolorem czerwonym. 
Drogi Panie Jacku!

Jest Pan jedynym Jackiem bliżs zym moim znajomym (zresztą, i dalszych znajomych tego imienia mam mało: nasuwają mi się na myśl teraz tylko Woźniakowski i ksiądz Robak), więc też nigdy nie miałem do czynienia ze sprawą Imienin Jacka właśnie, ale, zupełnie przypadkiem - rzuciwszy dzisiaj okiem na kalendarz, zobaczyłem, że j u tr o jest Jacka; oczywiście, może być więcej Jacków w kalendarzu, więc też może jutro nie sa Pana Imieniny; je ż eli są, ślę Panu moc najgorętszych życzeń wraz z wyrazami szczerej przyjaźni, j e ż eli nie - proszę wybaczyć nietakt, ocenić dobre intencje.

Dziękuję Panu gorąco za miłe słowa o tomie V Nowej baśni; „temperatura” tego podziękowania o tyle jest daleka bardzo od zdawkowości, że nie jestem rozpieszczony podobnymi ocenami; np. Lichniakowi ${ }^{1}$ książka się nie podoba, Sarnowska Elżbieta zaś (i to mnie przygnębiło raczej), wyraziwszy kilka słów uznania dla strony językowej, mówiła o książce tak, że odniosłem wrażenie, że właściwie niczego nie "pochwyciła” $z$ tego, co naprawdę tam jest (dla autora) ważne. Np. zaskoczyła mnie pytaniem, czy ma ona słuszność, zakładając, że miesiące lancelot, walgierz, dobrynia sa przeze mnie zmyślone ${ }^{2}$. P o za ty m c is za (Czermińska przeczytała, ale ani słowa uwag; może i jej się to nie podoba?). Wie Pan już (choćby z mojej rozmowy z Mentrakiem [!] w „Kultura”3), że wyszedł tom V w 5000 egz[emplarzy] (IV - w 7000), zamiast przewidywanych umową 10000.

Mam do Pana kilka próśb:

1) rok temu, gdy radio „robiło” Srebrne orły ${ }^{4}$, mówił mi Krzysztoń, że w n umerze czerw cowym „Więzi” (czerw[ie]c 1968) ukaże się omówienie III części Twarzy księżyca przez Szpotańskiego; Krzysztoń delikatnie sygnalizował, że raczej będzie to pełna pasji (ale i zainteresowania też) polemika z moją „historiozofią” (powiedzmy nawet: napaść, - co ja zresztą wolę od niczego nie mówiących banałów). „Więź” wychodzi z 2-miesięcznym opóźnieniem; w sierpniu dostałem numer właśnie czerw cowy, ale sygnalizowanego dawno artykułu Szpotańskiego nie było. Pan jest bardzo blisko z „Więzią”... czy zechciałby Pan „wysondować”, dlaczego to się nie ukazało ${ }^{5} .$.

2) czy mógłby Pan dowiedzieć się, co się dzieje $z$ moją byłą żoną, panią Elżbieta Parnicka ${ }^{6}$ ? Adres jej jest (może raczej już był tylko, a dzisiaj jest też tylko adresem wdowy po zmarłym jej bracie, p. Zofii Jackowskiej) - Wrocław 21 (Oporów), ul. Solskiego 40 m. 2. - Telefonu domowego nie było, ale p. E[lżbieta] Parnicka pracowała w R.S.W. „Prasa” (telefon w jej pokoju biurowym był 3-40-31).

Piszę do Pana straszliwie zmęczony, ale też dniu ogromnie dla m ni e ważnym. Dzisiaj od 5-tej rano do 1-szej p[o] p[ołudniu] kończyłem \{jednym tchem Inne życie Kleopatry ${ }^{7}$. Jak na Parnickiego powieść... dziwna (z lat 1839-1859). CD. na odwrocie ${ }^{8}$ / CD. $\mathbf{z}$ od w r ot $\mathbf{u}^{9}$ Ściskam Pana gorąco, - Pani Teresie ręce czule całuję Teodor Parnicki ${ }^{10}{ }^{11}$

List na jednej karcie, zapisanej obustronnie granatowym i czerwonym atramentem. 
1 Zygmunt Lichniak (1925-2015) w imieniu IW PAX w 1956 roku (wspólnie z T. Englert) nawiązał łączność korespondencyjną z Parnickim (który przebywał wtedy w Meksyku). To zaowocowało wznowieniami krajowymi Aecjusza, ostatniego Rzymianina i Srebrnych orłów, potem zaś pierwodrukami wielu nowych powieści pisarza. Przeprowadził też ostatni wywiad z Parnickim - „Uparłem się, aby być pisarzem polskim” („Kierunki” 1988, nr 10). Parnicki bardzo cenił sobie jego zdanie. Zadedykował jemu oraz jego żonie Zofii (z Czartoryskich) Kordobę z darów. Powieść na tle dziejów XI wieku (Poznań 1988).

2 Nazwy miesięcy w Księdze nowej [...].

3 K. M ętrak, „Powieść to jakby rozwiazywanie łamigłówki...” Rozmowa z Teodorem Parnickim. „Kultura” 1968, nr 2, s. 1, 3.

Krzysztof Mętrak (1945-1993) - krytyk literacki i filmowy, dziennikarz. Ukończył polonistykę na Uniwersytecie Warszawskim. Związany m.in. z „Twórczością”, „Współczesnością” i „Kulturą”.

4 T. Parnicki, Srebrne orły. Adaptacja A. Li s ow ska-Niepokólczy cka. Reż. J. Owidzki (20 IX 1967, $65 \mathrm{~min}$ ).

5 Artykuł ukazał się dopiero w numerze pierwszym z 1969 roku.

6 Elżbieta Parnicka (1909-1983) - pierwsza żona Teodora Parnickiego (w latach 1934-1954). Małżonkowie utracili ze sobą kontakt wskutek zawieruchy wojennej. Później zamieszkała we Wrocławiu, pracowała w Robotniczej Spółdzielni Wydawniczej „Prasa-Książka-Ruch”.

7 T. Pa rnicki, Inne życie Kleopatry. Powieść z wieku XIX. Warszawa 1969.

8 Kolorem czerwonym.

9 Kolorem czerwonym.

10 Kolorem czerwonym.

11 Tekst zapisany na marginesie s. 2, a potem u góry s. 1.

Drogi Panie Jacku.

Pisałem do Pana przed trzema dniami, a dzisiaj przeczytałem w „Tygodniku Powszechnym" Pańską recenzję z tomu V Now[ej] baśni ${ }^{1}$. Cóż mam powiedzieć? Chy ba ty le: jestem głęboko wzruszony - tak wzruszony, jak już dawno nie byłem. Pan ws zystko zrozumiał, Pan ws zy stko przenikną; nawet niezbędna w recenzji (sprawa rozmiarów) selekcja i rozkład a kc en tów są właśnie takie, jak ja sam to odczuwam i rozumiem. Świetny finał recenzji. Powtarzam: Drogi Panie, jestem bardzo wzruszony!

LAPSUS CALAMI2: Rewel to, oczywiście, Estonia, a nie Łotwa ${ }^{3}$. I jeszcze jeden drobiazg: „wymordowanie czystej krwi białych Jafetydów” dokonało się ty lko na półkuli zachodn[iej] (czyli „Na Przeciwziemi”); dziełem było Indian i Metysów; z Pańskiego tekstu natomiast można by wnioskować, że w s z ę d z i e, tj. „i na Ziemi, i na Przeciwziemi”, czyli i w „świecie wschodnim”4.

Dziękuję Panu gorąco. Gorąco Pana ściskam

\section{Teodor Parnicki ${ }^{5}$}

\{PS. ${ }^{6}$ Czy mógłby osiagnnąc Pan, by redakcja (czy administracja) „Tyg[odnika] Powsz[echnego]" posłała mi 4-5 egz[emplarzy] te go numeru?\} ${ }^{7}$

List na jednej karcie, zapisanej obustronnie granatowym i czerwonym atramentem.

1 J. Łu ka si ew i c z, Baśń o naszym-nienaszym świecie. „Tygodnik Powszechny” 1968, nr 37, s. 4. Przedruk w: Republika mieszańców (1974).

2 Lapsus calami (łac.) - błąd w pisaniu. 

związku ponadpaństwowego ze stolicą w łotewskim Rewlu”.

4 Zob. ibidem: „Europa miała za sobą nieudaną wojnę z Chinami, wielkie pogromy Żydów, a również dość tajemnicze wymordowanie białych Jafetydów czystej krwi”.

5 Kolorem czerwonym.

6 Kolorem czerwonym.

7 Tekst zapisany na marginesie s. 2.

Drogi Panie Jacku!

Dziękuje gorąco za miły i ciekawy list; także i za przekazanie T. Banasiowi prośby o dotarcie do pani Elżbiety P. (prośba ta - zdaje się - poskutkowała). A czy był Pan łaskaw dowiedzieć się w „Więzi”, co się stało z artykułem Szpotańskiego o trzeciej części Twarzy księżyca?

Za jakieś 2-3 tygodnie ma wyjść w PAX'ie „Zabij Kleopatrę”; zaraz gdy dostanę egzemplarze autorskie, jeden poślę Panu. Zresztą, fragment końcowy „Zabij Kleopatrę" ukazał się właśnie teraz weszycie wrześniowym „Miesięcznika Literackiego"1.

Przypominam sobie, że małżonka Pańska - w odróżnieniu od większości imienniczek swoich - obchodzi swoje Imieniny w dniu Teresy M n i ej s z ej², - już więc właśnie teraz czas, bym w imieniu Eli i własnym przesłał dla Pani Teresy najserdeczniejsze gratulacje i życzenia, od siebie dla Pani załączając czułe ucałowania rąk, a od Eli moc \{goracych pozdrowień i uścisków.

Dłoń Pańską też ściskam gorąco!

Oddany - Teodor Parnicki $\left.{ }^{3}\right\}^{4}$

List na jednej karcie, zapisanej obustronnie granatowym atramentem i czerwonym długopisem.

T. Parni cki, „Zabij Kleopatrę”, „Miesięcznik Literacki” 1968, nr 9.

Zob. list 16, przypis 1.

Kolorem czerwonym.

Tekst zapisany na marginesie s. 2 .

Drogi Panie Jacku!

Pisał Pan, że niezadługo zobaczymy się w Warszawie. $Z$ niecierpliwością oczekuję tego spotkania. $Z$ wielką niecierpliwością. Mam też prośbę do Pana: w „Tyg[odniku] Powsz[echnym]” nr 48 (1036) z data ju tr zej s zą przeczytał[em] o wydaniu przez Ossolineum dzieła Dr Marzeny Pollakówny Kronika Piotra $z$ Dusburga ${ }^{1}$. Skoro Ossolineum właśnie to wydało, najłatwiej jest chyba dostać tę ksiażkę we W r o c ła w i u. Czy może Pan ją kupić \{dla mnie i przywieźć do Warszawy? Kosztuje 45 zł. Gdyby Pan wolał, mógłbym tę kwotę przekazać Panu pocztą, a ni e dopiero w Warszawie ją Panu zwrócić. 


\section{Z góry gorąco dziękuję. Najserdeczniej Panią Teresę i Pana pozdrawiam - Teo- dor Parnicki $\left.{ }^{2}\right\}^{3}$}

List na jednej karcie, zapisanej jednostronnie niebieskim i czerwonym atramentem.

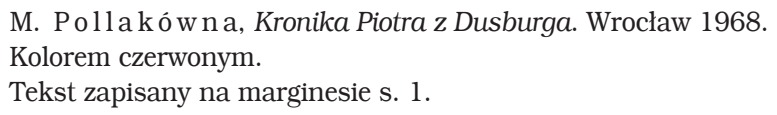

[grudzień 1968]

Drodzy Państwo!

I my z Elą też Państwu wraz z synkiem życzymy najszczęśliwszego roku 1969 z nadzieją szczególną na coraz to świetniejsze osiągnięcia Pana Jacka w dziedzinie krytyki i poezji.

\section{Szczerze oddany - Teodor Parnicki ${ }^{1}$}

Podłużna kartka pocztowa ze zdjęciem Rynku Starego Miasta w Warszawie. Słowa skreślone przez Parnickiego niebieskim atramentem i czerwonym długopisem wzdłuż s. 2.

$1 \quad$ Kolorem czerwonym.

Drogi Panie Jacku!

Pan dzisiaj jest jeszcze zapewne w Bydgoszczy, a ja dzisiaj jestem (właściwie od wczoraj, od soboty, od godziny 9 z minutami wieczorem ${ }^{1}$ ) szczególnie intensywnymi myślami przy Panu. Bo właśnie w czasie, wyżej czerwono zakreślonym, skończyłem pis ać tom szósty, a więc tym samym i cały cykl - Baśni nowej ${ }^{2}$. Jasna więc rzecz, starałem się sobie na de ws zy s tko wyobrazić, jak to przez Pana będzie przyjęte! CD. na odwrocie ${ }^{3}$ / CD. z odwro$\mathrm{tu}^{4}$ Czy Pan czytał recenzje Maciaga $z$ „Zabij Kleopatrę” w przedostatnim „Życiu Literackim”? Wydała mi się znacznie gł ę b i e j d r ą ż ą c a niż równoczesna Wegnera we „Współczesności” 6 . Pamięta Pan zdanie Maciaga: „nigdy jeszcze Parnicki nie był tak szalony"7 (brzmi to troche jak syrena karetki pogotowia z państwowe go szpitala psychiatrycznego!)?

Otóż „Zabij Kleopatrę”, a i Wylęgarnia dziwów to są zawrotne szczyty literatury najtrzeźwiej realistycznej. W z e s t a wi e n i u z tomem VI Nowej baśni występuję ja sam (ze znaczna porcją biografii własnej) jako egzaminowany i sądzony przez postacie $z$ wszystkich tomów poprzednich N[owej] b[aśni].

\section{Ściskam Pana serdecznie! Teodor Parnicki ${ }^{8}$}

List na małej kartce, zapisanej obustronnie niebieskim i czerwonym atramentem.

Kolorem czerwonym.

T. Parni cki, Nowa baśń. Cz. 6: Palec zagrożenia. Warszawa 1970.

Kolorem czerwonym.

Kolorem czerwonym. 
5 W. Ma ciąg, Wielkie idee i konkret wspótczesny. „Życie Literackie” 1969, nr 5, s. 10.

6 J. W e gn e r, Przystosowani do wieczności. „Współczesność” 1969, nr 3. Autor szkicu porównuje twórczość Parnickiego do surrealistów (Robbe-Grilleta, Butora), od czego pisarz się odżegnywał. Stąd w następnym akapicie uwaga o literaturze „najtrzeźwiej realistycznej”.

Jacek W e g n e r - krytyk literacki, dziennikarz, publikował m.in. w „Twórczości” i we „Współczesności”, związany z Uniwersytetem Warszawskim, autor książek i artykułów.

$7 \quad$ Maciag, op. cit., s. 10: „Takiego gwałtu na historii jako "zjawisku obiektywnym" nigdy jeszcze Parnicki nie popełnił, nigdy nie był tak szalony i tak w tym szaleństwie niezwykły".

8 Kolorem czerwonym.

Warszawa 22 ul. Zimorowicza 2 m. 10

Droga Pani Tereso!

28 maja 1969

Miałem od pana Jacka kartkę $\mathrm{z}$ Francji przed dwoma dniami, ale bez podania: 1) i adresu, 2) i terminu powrotu do Polski. Pani jednak chyba będzie jeszcze do niego do Francji pisała, byłby m więc bardzo Pani wdzi ęc zny za łaskawe przekazanie Panu Jackowi prośby ode mnie, żeby, gdy będzie wracał (wracać zaś chyba też będzie przez Warszawę), wpadł do mnie ko nie c z nie choćby na chwilkę tylko, - chcę mu osobiście wręczyć ś wi e ż o wydaną książkę moją Inne życie Kleopatry \{Raz jeszcze $z$ góry serdecznie za spełnienie tej mojej prośby dziękuję.

W imieniu żony i własnym ślę moc najgorętszych życzeń na chwilę obecną, i na całą przyszłość - nowego członka rodziny Państwa ${ }^{1}$.

Ręce Pani z wyrazami oddania całuję - Teodor Parnicki $\left.{ }^{2}\right\}^{3}$

List na jednej karcie, zapisanej jednostronnie niebieskim i czerwonym atramentem.

1 Chodzi o Krzysztofa, drugiego syna Łukasiewiczów, urodzonego właśnie w 1969 roku.

2 Kolorem czerwonym.

3 Tekst zapisany na marginesie s. 1

5 lipca 1969

\section{Drogi Panie Jacku!}

Z a raz po otrzymaniu $z$ Wrocławia już listu $z$ wiadomością o Pańskim powrocie z Francji wysłałem Panu poczta p o le c o n a egzemplarz książki Inne życie Kleopatry. Myślę, że Pan to dostał; myślę nawet też, że może już Pan to przeczytał. Byłbym ciekaw bardzo uwag Pańskich właśnie o tej książce.

W c ze rw c o wy m numerze „Nurtu” (Poznań) wydrukowano fragment tomu VI Nowej baśni $i^{2}$ Poza tym zwracam Pańską uwagę na artykuł Trzebuchows ki e go w nr. 6 (więc też z c z e r w c a) PAX’owskiego \{miesięcznika „Życie i Myśl”3 o „Zabij Kleopatrę" . Szczególnie uderzył mnie fi n ał tego artykułu, - wydało mi się nagle, że ostatnich trzydziestu lat w ogóle nie było...

Dłoń Pańską ściskam gorąco - Teodor Parnicki ${ }^{5}{ }^{6}$ 
List na jednej karcie, zapisanej jednostronnie niebieskim i czerwonym atramentem.

„Nurt” - czasopismo kulturalno-społeczne, ukazujące się w latach 1965-1989.

T. Pa rn ic ki, Nowa baśń. T. 6: Palec zagrożenia. „Nurt” 1969, nr 6.

„Życie i Myśl” - czasopismo kulturalne o profilu katolickim, ukazywało się od roku 1950. Wydawane m.in. przez PAX.

4 P. Trzebuchowski, Alchemia słowa Teodora Parnickiego. „Życie i Myśl” 1969, nr 5. Krytyk zarzuca Parnickiemu, że „Zabij Kleopatrę” niczego czytelnika nie uczy ani też nie urzeka pięknem. Wedle Trzebuchowskiego autor powieści bawi się w rebusy intelektualne, a nie wykorzystuje możliwości stania się wielkim pisarzem polskim i katolickim, na którego czekają czytelnicy.

5 Kolorem czerwonym.

6 Tekst zapisany na marginesie s. 1.

Drogi Panie Jacku!

W sobote 5 li p c a wysłałem równocześnie listy do Pana i do Pozn[ańskiego] T[owarzyst]wa Przyjaciół Nauk i do pewnej Pani w Krakowie. Okazało się, żem pomylił koperty, i list do Pani z Krakowa przyszedł do Pozn[ańskiego] T[owarzyst]wa Przyj[aciół] Nauk. Może więc także i do koperty, do Pana zaadresowanej, włożyłem list niewłaściwy CD. na odwrocie / \{CD. z odwrotu, czyli przeznaczony dla Pozn[ańskiego] T[owarzyst]wa Przyj[aciół] Nauk. Jeżeli właśnie tak się stało, może mi Pan łaskawie ów list odeśle?\} ${ }^{1}$

W liście do Pana 1) pytałem o Pańskie wrażenia z lektury Innego życia Kleopatry; 2) zwracałem Pańską uwagę na artykuł Trzebuchowskiego w nr. 6 (czerwcowym) PAX'owskiego „Życia i Myśli”; 3) sygnalizowałem Panu ukazanie się fragmentu z tomu VI \{Nowej baśni w numerze czerwcowym poznańskiego „Nurtu”.

\section{Ściskam Pana serdecznie. Teodor Parnicki $\left.{ }^{2}\right\}^{3}$}

List na małej kartce, zapisanej obustronnie niebieskim atramentem.

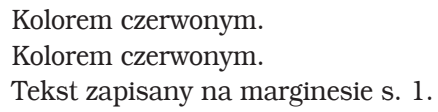

Już dość d a w no temu posłałem Panu Inne życie Kleopatry. Z wy kl e potwierdzał Pan nadchodzenie ksiazżek ode mnie, - teraz potwierdzenia ni e było. Zaczynam się niepokoić - może książka ta w ogóle do Pana nie dotarła? Proszę o szybką wiadomość.

\{Moc pozdrowień dla wszystkich Państwa oraz dla Urszuli Kozioł i p. Przybyla$\mathrm{ka}^{1}$ lączę - Teodor Parnicki\} ${ }^{2}$ 
$1 \quad$ Kolorem czerwonym.

2 Tekst zapisany na marginesie s. 2.

Drogi Panie Jacku!

Dla Pani Teresy, dla Pana samego i dla synów Państwa ślę i od Eli, i od siebie moc najlepszych życzeń na dni świąteczne i na cały rok 1970.

\section{Dłoń Pańską ściskam serdecznie}

\section{Teodor Parnicki}

PS. Pozwoliłem sobie prosić redakcję poznańskiego miesięcznika „Nurt”, by posłali Panu egzemplarz numeru styczniowego ${ }^{1}$, gdzie ma zostać wydrukowany \{fragment początkowy mojej ostatniej, jak dotąd, powieści pt. Tożsamośćc . $^{3}$

List na kartce, zapisanej jednostronnie zielonym flamastrem i czerwonym długopisem.

1 Kolorem czerwonym.

2 T. Parnicki, Tożsamość. Powieść. Warszawa 1970. Początkowy fragment powieści ukazał się w „Nurcie” w nrze 1 z 1970 roku.

3 Tekst zapisany na marginesie s. 1 .

Drogi Panie Jacku!

Wysłałem do Pana powinszowania noworoczne we wtorek 23-go, we środę 24-go nadszedł list Pański z 20-go. Powinszowania moje były lakoniczne, nawet suche, co i nie dziw, gdyż w ogóle nie byłem pewien, czy powinienem do Pana pisać, bo przecież może Panu wcale ode mnie list przyjemności nie sprawiłby. Toteż $\mathrm{P}$ a ń s k i był dla mnie bez przesady najprzyjemniejszą niespodzianką wigilijno-świąteczną. Postawię sprawę szczerze: byłem pewien, że Pan postanowił „zerwać ze mną”, a co najmniej już „możliwie daleko ode mnie się odsunąć”. Powód? Domysły snułem najrozmaitsze - najprawdopodobniejszym z nich wydawał mi się związany z Pańską reakcją na „obie Kleopatry”, może bardziej jeszcze na Inne życie niż na „Zabij...” Jest to domysł - w świetle Pańskiego listu - absurdalny, okazuje się, ale liczyłem się z tym, że wielu ta właśnie książka może zrazić do mnie, a i wiem, że zraziła... Zresztą, może i Pan też zauważył zgodne milczenie krytyki wokół tej książki (wyszła w maju, a recenzję miała jedna, a i to w organie wydawców, - tj. w „Kierunkach” ${ }^{1}$ ), - ktoś mi zaś w sam dzień wigilijny powiedział, że może milczenie to rozumieć należy jako ge st (czy to krytyki, czy jakichś władz ponad krytyka) uprzejmości wobec mnie, - właściwie wobec pisarza, który niedawno wrócił do Polski... czyli innymi słowy: nie ma recenzji, bo gdyby były, musiałyby być nieprzyjazne czy wręcz napastliwe... Nie wiem, jak dalece takie stawianie sprawy jest (lub „byłoby”, lub „mogłoby być”) zgodne $z$ prawda, - że mógłbym subiektywnie uznać je za zgodne z prawdą, dowód choć w tym, czym tłumaczyłem sobie Pań s k i e właśnie milczenie, a to milczenie nie tylko krytyka, ale i przyjaciela czy choćby nawet tylko zna- 
jomego... Rzecz inna, może to Pana zadziwi, zaskoczy nawet, - nie odgadnie Pan, kiedy i jak zostało zasiane pierwsze ziarno, $\mathrm{z}$ którego wyrosło po czterech z góra latach Inne życie Kl[eopatry]. Przypomnę Panu. Byłem wtedy pierwszy raz w Polsce - mieszkałem u Sobieszczańskich na Mokotowskiej (była więc to chyba wiosna już 1964), - odwiedził mnie Pan tam (n i e była to pi e rws za Pańska tam wizyta), byłem świeżo po obejrzeniu Dziadów w interpretacji Skuszanki w Teatrze Polskim², i wspólnie z Panem komentowaliśmy położenie w owej interpretacji szczególnego nacisku na część Drugą (czyli na mistykę zabobonnie ludową) kosztem mistyki (znacznie bliższej katolicyzmu dogmatycznego, choć też nie nazbyt bliskiej, jak sądzę) w części Trzeciej...

Zastanawia mnie w liście Pańskim sformułowanie: „Trzeba by mi było zrewidować wszystko na temat „Parnickiego powieści”, itd. Czy Pan jest pewien, że tr z e b a zrewidować, i to aż w s zy s tko o Czy obie „Kleopatry” nie wydają się Panu n a tu r a ln y m ciagiem dalszym (nie używam zwrotu „naturalnym rozwojem dalszym", bo przecież także i dla Pana może to być dekadencja, degeneracja nawet, nie rozwój) drogi mojej, - tej samej drogi, która kiedyś wiodła i przez 3 min[uty] po 3, i przez Aec[jusza], i przez Sr[ebrne] orły, i Koniec „Zgody Narodów”...? ${ }^{3}$ Wszystko to jest to s a mo, to s a mo wędrowanie \{po tym samym labiryncie, $z$ tym tylko przecież, że nie tylko Pan (czy Sł[awomir] Cieślikowski np.), ale i ja sam nawet nie wiem, przeszedłszy z korytarza np. L do korytarza np. M, dokąd znaki orientacyjne na ścianach korytarza M CD. na margine sie na odwrocie ${ }^{4}$ CD. $z$ margine s $\mathrm{u}^{5}$ na odwrocie - mnie $\mathrm{z}$ kolei skierują, ale skierować muszą tylko do korytarza $\mathrm{N}$ (bez względu na to, co może mnie w korytarzu N czekać), gdyż in n e go żadnego wyjścia $z$ korytarza $M$ nie ma, a i droga powrotu do korytarza L (CD. na marginesie str. II) ${ }^{6}$ / CD. z margin es u na str. III ${ }^{7}$ niemożliwa, gdyż drzwi, łączące korytarz L i M zatrzasnęły się „na głucho”, ledwiem z L do M przeszedł. Rzecz jasna, mógłby Pan powiedzieć: nadaremne to wędrowanie. Gdyż z la biryntu wyjścia nie ma, czeka mnie tam tylko unicestwienie, - lub może chciałby CD. na marginesie na odwrocie ${ }^{8}$ / CD. z marginesu na odwrocie ${ }^{9}$ Pan zawtórować Lichniakowi domysłem, że ja już byłem przy wyjściu $z$ labiryntu, a co najmniej już wiem, gdzie wyjście jest, ale tak się przyzwyczaiłem po korytarzach błądzić, że po prostu wyjść już $\mathrm{z}$ labiryntu nie chcę... wł a ś $n$ i e teraz wchodzę w korytarz powiedzmy P (powieść Muza dalekich podróż $y^{10}$ ), nie wiem, co w nim znajdę i co on ze mną lub ze mnie uczyni, nim znajdę się u jego wyjścia... czy mnie raczej znów tylko u przejścia w korytarz R... Raz jeszcze ślę najgorętsze życzenia na rok $1970^{11}$ - oddany Teodor Parnicki $\left.{ }^{12}\right\}^{13}$

List na dwóch kartach, zapisanych obustronnie niebieskim i czerwonym atramentem oraz zielonym flamastrem. W rogu s. 2-4 pojawia się numeracja rzymska.

1 A. Polkowski, Jazda na hipogryfie. „Kierunki” 1969, nr 39. „Polska Bibliografia Literacka” odnotowuje w roku 1969 jeszcze recenzję Z. Dolecki g o (Świat. Historia. Literatura. „Słowo Powszechne” 1969, nr 141). Pisał o tej książce J. W e g n e r (Skazani na poszukiwania. „Współczesność” 1970, nr 4). Za to „Zabij Kleopatrę” doczekała się kilkunastu recenzji.

2 Dziady A. Mickiewicza w interpretacji K. Skuszanki miały premiere 15 II 1964.

3 Powieści z początku drogi twórczej T. Parnickiego: Trzy minuty po trzeciej. „Lwowski Kurier Poranny" 1929, nry 414-604, 1930, nry 1-23; Aecjusz, ostatni Rzymianin (1937); Srebrne orty. Powieść historyczna. Jerozolima 1944 (wyd. 1 krajowe: Wrocław 1949); Koniec „Zgody Narodów”. Powieść z roku 179 przed narodzeniem Chrystusa. Paryż 1955 (wyd. 1 krajowe: Warszawa 1957). 


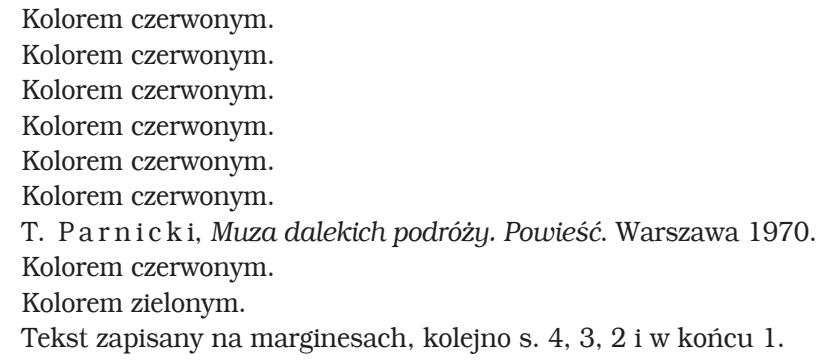

Drogi Panie Jacku!

W poniedziałek, 13 lipca wysłałem Panu tom VI Nowej baśni (Palec zagrożenia). Proszę uprzejmie o łaskawą wiadomość, czy otrzymał Pan. Pozdrawiam Państwa najserdeczniej - Teodor Parnicki ${ }^{1}$

Mała kartka, zapisana jednostronnie niebieskim i czerwonym atramentem.

1 Kolorem czerwonym.

Kochany Panie Jacku,

We wtorek, 24/XI - wysłałem Panu poczta p o l e c o n a egzemplarz Muzy dalekich podróży. Uprzejmie Pana proszę dać mi łaskawie znać, czy książka ta do Pana dotarła...

D z i s i aj dostałem „Tygodnik Powszechny” i przeczytałem Pańskie omówienie zakończenia Nowej baśni $i^{1}$. Finał recenzji jest głęboko wzruszający i n a p raw dę całkowicie uzasadniający celowość poświęcenia i tylu lat, i tylu, tylu stron papieru przeze mnie \{temu cyklowi, - ale o całości recenzji nie ośmieliłbym się wypowiadać, czy jest ona istotnie tym ws zystkim już, co mógłby i chciał Pan o Palcu zagrożenia właśnie od siebie, Jacka Łukasiewicza, powiedzieć... Rzecz jasna, ja sam mogę przecież błędnie (CD. na odwrocie) $\left.)^{2}\right\}^{3}$ / CD. $\mathbf{z}$ o d w r o t u $\mathbf{u}^{4}$ zakładać, że Pana $\mathrm{np}$. powinny by szczególnie zainteresować motywy mojego stosunku do tradycji poezji romantycznej czy też problem „Należy czy nie należy Nowa baśń do literatury polskiej”, - \{lub też motyw „machin oblężniczych”; SUI GENERIS wieszczenie historiozoficzne, wyrażone tuż tuż już w finale książki: „A może my byśmy zrobili porządek tutaj?" $\}^{6}$ jako że może Pana naprawdę akurat coś zupełnie innego bardziej jednak interesować, - poza tym wprost niemożliwe byłoby dla krytyka wdawać się w szczegóły (choć w jeden Pan się wdał: bose stopy kobiece...) - i ogólne moje wrażenie jest takie: zamierzył Pan napisać szkic syntetyzujacy i o jako takim wła śn ie należy o nim powiedzieć, że nic nie można ani odjąć, \{ani dodać... Najsłuszniejsza uwaga ściśle krytyczna (i sprawie- 
dliwie krytyczna) to jest ta, z jaką Pan wchodzi, że się tak wyrażę, w „okop”, podbudowywany materiałem Miciński-Kant... Wie Pan? gdy pisałem Stowo i ciało, r ozu mow a ł e m, że powinna to być książka 240 -stronicowa, ale rozumowanie nie przemogło... Czy - niestety? Chyba tak, lecz z drugiej strony - np. Ulysses... obszerniejszy wszak nawet i od Muzy dallekich] podr[óży]??! Ale znowuż rzec przecież dałoby się, a może i trzeba: „PARVA MAGNIS COMPARARI NON LICET”7.

Ściskam Pana bardzo serdecznie Teodor P. 8$\}^{9}$

\{PS. ${ }^{10}$ Po raz drugi ściskając Pana w tym liście b[ardzo] serdecznie, - łączę też moc serdeczności dla Pani Teresy i synów ${ }^{11}-$ T. P. $\left.{ }^{12}\right\}^{13}$

List na jednej karcie, zapisanej obustronnie niebieskim atramentem oraz flamastrami czerwonym i zielonym. Na s. 1 słowa Parnickiego - pionowo, z dopiskami na lewym marginesie. Na s. 2 z kolei - po prawej stronie kartki (odwróconej poziomo), następnie po lewej stronie. Dopiski znajdują się na dole po lewej stronie i na środku u góry (dopisek „do góry nogami”).

1 J. Łukasiewicz, Ostatni tom „Nowej baśni”. „Tygodnik Powszechny” 1970, nr 48. Przedruk w: Republika mieszańców (1974).

2 Kolorem czerwonym.

3 Tekst zapisany na marginesie s. 1.

4 Kolorem czerwonym.

5 W tomie 6 Nowej baśni odbywa się nad autorem sąd (miejscami w formie egzaminu), którego dokonują wszystkie postaci cyklu. Akcja powieści rozgrywa się częściowo w XIX wieku, a zatem pojawia się tu problem poezji romantycznej i romantyzmu w ogóle, który Parnicki będzie drążył jeszcze w Muzie dalekich podróży i innych powieściach. Motyw tożsamości jest z kolei widoczny w całej twórczości Parnickiego. Można doszukiwać się przyczyn częstszego pojawiania się tej tematyki wraz z wątkami autobiograficznymi w związku z przyjazdem pisarza na stałe do Polski (rok 1967). O ile Parnicki był twórca polskim i czuł się Polakiem, o tyle jednak w jego biografii silnie zaznaczył się fakt narodzin w Niemczech i wpływy rosyjskie (język rosyjski był pierwszy). Palec zagrożenia próbuje zmierzyć się z tymi właśnie problemami.

$6 \quad$ Tekst zapisany po lewej stronie kartki.

7 „Parva magnis comparari non licet” (łac.) - „Nie godzi się, żeby rzeczy małe były porównywane Z wielkimi” (sentencja często pojawiająca się w powieściach Parnickiego).

8 Kolorem zielonym.

9 Tekst zapisany po lewej stronie kartki, najpierw na środku, potem u góry stronicy.

10 Kolorem czerwonym.

11 Kolorem zielonym.

12 Kolorem czerwonym.

13 Tekst zapisany u góry s. 1.

Drogi Panie Jacku!

24 li s t o p a d a wysłałem do Pana Muzę dalekich podróży, a potem list z zapytaniem, czy Pan tę przesyłkę dostał. Tymczasem wyszła Tożsamość (w „Czytelniku” wydawano ją od początków czerwca roku 1969 do wczoraj, gdy PAX wydawał Muzę od kwietnia 1970 do początków listopada 1970 - różnica zdumiewająca!), ale bałbym się i ją też Panu wysłać przed upewnieniem się, że Muzę Pan dostał.

W tym samym liście pozwoliłem sobie na parę uwag na marginesie Pańskiej recenzji z VI tomu Nowej baśni (musiał ten list bardzo Pana zmęczyć, gdyż dopiski i dopiski do dopisków szły wkoło... i wkoło... a to w miarę jak mi się nasuwało na 
myśl coraz to coś nowego!...). Ale już po wysłaniu tego listu - odczytując po raz trzeci i czwarty tę Pańską recenzję, - oceniłem w pełni świetną c zy s to p i s a r s ką jej formę, a bardziej jeszcze oceniłem i później jeszcze, w zestawieniu z formą olbrzymiego eseju o Nowej baśni na str. 1-2 ostatniego numeru „Współczesności”” (autor tego eseju, Chojnacki, też napisał pracę doktorską o mnie, ale, w przeciwieństwie do Czermińskiej, jeszcze tego doktoratu nie zrobił, - choć tezę swoją dał mi do przeczytania jeszcze w roku 1967...).

Drogi Panie Jacku, bezs pornie czytał Pan felieton Kijowskiego Powieść w numerze „Tyg[odnika] Powsz[echnego]”3, bezpośrednio następnym po tym, w jakim się ukazała Pańska recenzja. Proszę Pana o przyja cielska przysługę: niech mi Pan \{łaskawie napisze - czy mam rację, sądząc że ta Kijowskiego Powieść to jest właśnie VI tom Nowej baśni (Sadkowski twierdzi, że nie, ale ja myślę, że on się myli). Początkowo i mnie samego (po drugim czytaniu) zaczął zbijać $z$ tropu Balzac z końcowego zdania, - ale potem (dopiero potem) zauważyłem dedykację Alfie $^{4}$ CD. na odwrocie ${ }^{5}$ / CD. $\mathbf{z}$ od wrot $\mathbf{u}^{6}$ i właśnie ta dedykacja wydała mi się argumentem rozstrzygającym - na rzecz domysłu, że to o mnie Kijowski pisał... Będę bardzo Panu wdzięczny za od w r o t ną odpowiedź - ściskam Pana serdecznie - Teodor Parnicki ${ }^{7}{ }^{8}$

\{P S. ${ }^{9}$ Zapowiedział Pan odwiedzenie nas, we wrze śni u, ale nie zgłosił się Pan T. P. $\left.{ }^{10}\right\}^{11}$

List na jednej karcie, zapisanej obustronnie niebieskim atramentem oraz flamastrami czerwonym i zielonym.

1 W „Czytelniku” ukazały się Tożsamość, Przeobrażenie, Sekret trzeciego Izajasza oraz Historia w literature przekuwana.

2 Chodzi o esej A. Chojn a cki e go W labiryncie historii („Współczesność” 1970, nr 25).

Antoni Chojnacki (ur. 1936) - krytyk i literaturoznawca, wówczas związany z Uniwersytetem Warszawskim, potem z Akademią Podlaską i Akademią Humanistyczno-Ekonomiczną w Łodzi, autor książki Parnicki $w$ labiryncie historii (Warszawa 1975).

3 A. Kij ow ski, Powieść. „Tygodnik Powszechny” 1970, nr 49. Chodziło tu o J. Andrzejewskiego, lecz w tym czasie nie można było wymieniać jego nazwiska w druku. Np. w Zniewolonym umyśle Cz. Miłosza Andrzejewski występuje jako Alfa. Zob. A. Kij ow s ki, Powieść, czyli miazga. W: Gdybym był królem. Poznań 1988. W wersji książkowej szkic posiada dedykację: „Jerzemu Andrzejewskiemu".

4 Alfa to jedna z postaci Nowej baśni (t. 6).

5 Kolorem czerwonym.

6 Kolorem czerwonym.

7 Kolorem czerwonym.

8 Tekst zapisany na marginesie s. 2, następnie na marginesie s. 1.

9 Kolorem czerwonym.

10 Kolorem zielonym.

11 Tekst zapisany na marginesie s. 1.

Tak właśnie i było: pocztówka z Aten wytłumaczyła mi tajemnicę Pańskiego milczenia, - zresztą, mówiła mi i Sarnowska też, że Pan dostał stypendium na tego 
typu podróż zagraniczną... Pomny na Pańskie relacje $z$ wrażeń z podróży do Francji, - myślę, że nawet ta k a podroż jak ostatnia dać musiała Panu bardzo wiele... Ma Pan nieporównanie więcej np. choćby ode mnie samego - wrażliwości na aspekt czysto estetyczny świata zewnętrznego, i podejrzewam, że jedna bytność na Akropolu dała Panu znacznie więcej, niż mnie dała 7 czy 8 w maju 1939 roku ${ }^{1}$. \{Zresztą, dla mnie Akropol miał więcej uroku oglądany z zewnątrz, a to z góry... Wdrapywałem się na szczyt góry Lykabeth - widziało się stamtąd nie tylko Ateny, ale i Salaminę, i Eginę.... $\}^{2}$

A teraz taka sprawa wcale intrygująca: $z$ Warszawy można już łączyć się z Wrocławiem telefonicznie bezpośrednio, nakręcając numer 871... Otóż z Banasiem w ten sposób łączyłem się już kilkakrotnie, ale ilekroć dzwoniłem do Pana (a próbowałem chyba ze 20 razy), Pański telefon (6-19-69) stale dawał sygnał „zajęty”...

Gdy minie fala świąteczna na poczcie, poślę Panu Tożsamość - na razie zaś tą droga ślę Państwu najlepsze życzenia na nowy rok oraz wyraz nadziei, że spędzaja Państwo czas świąteczny możliwie najmilej...

\section{Szczerze oddany Teodor Parnicki ${ }^{3}$}

List na jednej karcie, zapisanej obustronnie niebieskim atramentem i czerwonym flamastrem.

1 Stypendium na wyjazd do Bułgarii, Grecji i Włoch dostał Parnicki wraz z drugą nagrodą w konkursie Polskiej Akademii Literatury, za Aecjusza, ostatniego Rzymianina. Podróż odbył wiosną i latem 1939.

2 Tekst zapisany na marginesie s. 1.

3 Kolorem czerwonym.

[grudzień 1971]

Drogim Państwu Teresie i Jackowi Łukasiewiczom wraz z synami najszczęśliwszego roku $1972^{1}$ życza najserdeczniej

\section{Ela i Teodor Parniccy ${ }^{2}$}

Podłużna, składana kartka pocztowa. Na s. 1 widnieje napis: „Szczęśliwego Nowego Roku”, oraz kolorowe rysunki pędzących po śniegu sań. Wewnątrz, po prawej stronie, słowa skreślone przez Parnickiego flamastrami zielonym i czerwonym.

1 Kolorem czerwonym.

2 Kolorem czerwonym.

[grudzień 1972]

Drogim Państwu Teresie i Jackowi Łukasiewiczom wraz z Synami najszczęśliwszego roku $1973^{1}$ życzą najserdeczniej Ela i Teodor Parniccy ${ }^{2}$

Podłużna, składana kartka pocztowa. Na s. 1 widnieje napis: „Szczęśliwego Nowego Roku”, oraz kolorowy rysunek przedstawiający średniowiecznego minstrela, który gra dla siedzącej panny. Wewnątrz, po prawej stronie, flamastrami zielonym, czerwonym i fioletowym - słowa skreślone przez Parnickiego.

1 Kolorem czerwonym.

2 Kolorem fioletowym. 
48

Środa, 11 kwietnia 1973

Drogi Panie Jacku!

Dostałem dzisiaj XVI tom dzieł Juliusza Słowackiego (Król-Duch) ${ }^{1}$ - dziękuję Panu najserdeczniej! Ze swojej strony posłałem Panu wczoraj (wtorek, 10/IV), a też pocztą pole c o na - swoją powieść Staliśmy jak dwa sny $y^{2}$. Proszę także o potwierdzenie nadejścia, $z$ tym przecież, że proszę również, by napisał mi Pan, ile w y d ał na ten tom Słowackiego (na okładce ksiażzi ani w ogóle w książce nigdzie nie mogłem znaleźć ceny). Stanowczo proszę n i e stawiać sprawy tak, że wymieniliśmy z sobą prezenty książkowe: ja Panu posłałem jeden ze swoich a u t or s k i c h (czyli grat i s o w y c h) egzemplarzy, a Pan Słowackiego k u pił! Chciałbym więc przekazać Panu należność możliwie be z z wło c zn i e, chyba iż wybiera się Pan znów bardzo niedług o do Warszawy i wtedy znów przyszedłby Pan do nas na obiad np. - i wtedy bym Panu należność tę wypłacił do rąk własnych.

Pozdrawiam Panią Teresę i Pana, i synów Państwa bardzo serdecznie! ${ }^{3}$

Teodor Parnicki ${ }^{4}$

\{PS. ${ }^{5}$ Proszę Pana przekazać ode mnie wiele serdeczności dla Pani Urszuli Kozioł. ${ }^{6}{ }^{7}$

List na jednej karcie, złożonej wpół, zapisanej na s. 1 i 3 flamastrami zielonym, czerwonym i niebieskim.

$1 \quad$ Zob. listy 17, 20, 26. Chodzi o tom 16 Dzieł wszystkich J. Sło w a c k i e go pod redakcją J. Kl e inera i W. Floryana $z 1972$ roku.

2 T. Parnicki, Staliśmy jak dwa sny. Warszawa 1973.

3 Kolorem niebieskim.

4 Kolorem czerwonym.

5 Kolorem czerwonym.

6 Kolorem niebieskim.

7 Tekst zapisany na marginesie s. 1.

[grudzień 1975]

Drogi Panie Jacku!

Jest chyba rzeczą słuszną, ażebym Idealnemu Czytelnikowi Nowej baśni w osobie Pańskiej (jak też dla Pani Teresy i synów Państwa) najserdeczniejsze powinszowania od Eli i od siebie na rok $1976^{1}$ przesłał na odwrocie widoku pozostałości Tollana Tolteków

\section{Szczerze Panu oddany Teodor Parnickd ${ }^{2}$}

Kartka pocztowa. Na s. 1 zdjęcie meksykańskich ruin. Cała s. 2 zapisana przez Parnickiego flamastrami zielonym i czerwonym.

1 Kolorem czerwonym.

2 Kolorem czerwonym. 
Drogim Państwu Teresie i Jackowi Łukasiewiczom wraz z Synami najszczęśliwszego roku $1977^{1}$ życzą najserdeczniej Ela i Teodor Parniccy ${ }^{2}$

Kartka pocztowa. Na s. 1 zdjęcie zegara i martwej natury. Cała s. 2 zapisana przez Parnickiego flamastrami zielonym i czerwonym.

1 Kolorem czerwonym.

2 Kolorem czerwonym.

31/XII 1977

Drogim Państwu Teresie i Jackowi Łukasiewiczom wraz z Synami najszczęśliwszego roku $1978^{1}$ życzą najserdeczniej

\section{Ela i Teodor Parniccy}

Vide wewnatrz

\section{Drogi Panie Jacku!}

Ogarnia mnie niepokój - a co najmniej już nękają wątpliwości - czy te nasze p owinszowania now oroczne naprawdę do Państwa dotra. Na starość psuje mi się pamięć - mgliście uświadomiłem sobie, że zmienili Państwo adres (czyli n i e mieszkaja już na ulicy Pereca 44), ale absolutnie nie mogłem sobie przypomnieć nowego adresu (ani też go nie mogłem odnaleźć w swoim notatniku $z$ adresami). Wczoraj dzwoniłem do Pana na dawny telefon (6-99-69), nikt się nie odezwał; założyłem, że może zmieniono Panu numer telefonu, więc zadzwoniłem też do Wrocławia - do swego przyjaciela, Tadeusza Banasia; nie było go w domu, poprosiłem więc jego żonę, by znalazła w książce telefonicznej Wrocławia J a c ka Ł u ka s i ewi c za - p. Banasiowa powiedziała mi, że J a ck a Ł[ukasiewicza] w książce telefonicznej nie ma, ale okazało się że jest Łukasiewicz Teresa, dostałem jej telefon, ale po połączeniu się dowiedziałem się, że ta Teresa Ł[ukasiewicz] nie jest żoną Jacka L[ukasiewicza]. Z kolei dzisiaj zadzwoniłem do Związku Literatów - podali mi i adres, i telefon, ale czy dobrze usłyszałem? (bo oto i słuch mi ostatnio bardzo się psuje) Usłyszałem: Popowicka $9 \mathrm{~m}$. 6. Telefon: 355-16. Ale dzwoniłem dzisiaj kilkakroć do Wrocławia na ten numer i nikt się nie odezwał.

\section{Ściskam Pana bardzo serdecznie! - Teodor P. ${ }^{3}$}

List na karcie papeteryjnej z okolicznościowymi nadrukami noworocznymi. Na s. 1 Parnicki skreślił życzenia, na s. 2 znajduje się list zapisany niebieskim atramentem i czerwonym flamastrem.

Kolorem czerwonym.

Kolorem czerwonym.

Kolorem czerwonym. 


\section{Drogi Panie Jacku!}

Nie kontaktowałem się $z$ Panem od bardzo dawna, z czego bynajmniej jednak nie wynika, ażebym nie był myślami $z$ Panem (czy też przy Panu) - wręcz przeciwnie: od pięciu miesięcy często myślę o Panu, a to $\mathrm{w}$ związku $\mathrm{z}$ pewną niezmiernie ważną dla mnie sprawą i nieraz chciałem zabrać się do pisania do Pana, ale powstrzymywała mnie właśnie świadomość „pustki, jaka powstała między nami” od dnia chyba aż tak odległego, gdy był Pan u nas na obiedzie bezpośrednio po moim „występie prelegenckim” w klubie „Krag”” (w lokalu im. Wł[odzimierza] Pietrzaka, czyli PAX'owskim) w roku chyba 1974 albo nawet aż 1973, a był to „występ” na temat „trójwymiarowy model powieści historycznej”" Przypominam sobie, że w toku tego obiadu u nas mówiłem Panu o swoim projekcie powrotu literackiego do czasów pierwszych władców Piastowskich z szczególnym skoncentrowaniem się na motywie opisanego w kronice Thietmara zachowania się Mieszka I w stosunku do próby szantażu ze strony czeskiego Bolesława („nie wypuści - a nawet zabije sprzymierzonych z Mieszkiem rycerzy saskich, jeżeli Mieszko nie odda mu takich to a takich ziem etc..., etc..."). Otóż projekt ten (choć w wykonaniu zawrotnie aż odmiennym od pierwotnego zamierzenia) zrealizowałem w postaci powieści pt. Dary z Kordoby ${ }^{2}$, która zdołałem napisać dopiero w roku 1979 i którą W[ydawnic]two Poznańskie opublikowało późną jesienią roku 1981 ... Nie wiem, czy miał Pan tę książkę w rękach - egzemplarza od siebie nie zdażżłem do Pana wysłać, gdyż do mnie samego egzemplarze autorskie dotarły w końcu listopada 1981, a od połowy mniej więcej grudnia 1981 obowiązuje przepis o zakazie przyjmowania przez pocztę przesyłek z książkami ${ }^{3}$... Jeszcze w maszynopisie czytali Dary z Kordoby Zygmunt Lichniak i Wacław Sadkowski, i zdaniem obu ich jest to książka gorsza od moich dawniejszych... W roku następnym (1980) uporałem się nareszcie z pracą (ciagnącą się od roku 1973 - w ten sposób ciagnącą się, że wciąż zmieniałem różne wersje) nad olbrzymia rozmiarami (około 900 stron maszynowych) powieścia Sekret trzeciego Izajasza 4 , stanowiąca kontynuację Tożsamości i Przeobrażenia, wydanych przez „Czytelnika” we wczesnych latach 70-tych. I tę też powieść dałem do przeczytania w maszynopisie i Lichniakowi, i Sadkowskiemu, i obaj ocenili ją s u r o w i ej je s z c ze niż Dary z Kordoby, mimo, jaką to, zreszta, ocenę, „Czytelnik” zaakceptował Sekret 3-go Izajasza do druku, z tym przecież, że ja sam wyraziłem gotowość zgodzenia się na skrócenie objętości powieści (z 40 arkuszy na 33), pod warunkiem jednak, że skrótów dokonywaliby wydawcy, a nie ja sam, w myśl zasady, że „najbardziej nawet doświadczony chirurg nie operuje własnych dzieci”...

W następnym roku napisałem jeszcze jedna powieść (czyli w roku 1981), także bardzo obszerną, choć nie w tym samym stopniu, co Sekret trzeciego Izajasza, gdyż licząca 651 stron. Czy Pan wie, kto był „,́́więty Hermenegild”? (jeżeli nie wie Pan, łatwo może chyba wiedzę taką nabyć $z$ jakiejś obszerniejszej encyklopedii katolickiej, a może nawet $\mathrm{w}$ jakimś studium 〈czy rozdziale〉 na temat walki arianizmu $\mathrm{z}$ katolicyzmem w Hiszpanii w wieku VI-tym). Otóż historii jest wiadome, że syn świętego Hermenegilda i Ingundy, królewny z rodu Franków Merowingów, zowiący się Atanagild, osierocony w niemowlęctwie, znalazł się w Konstantynopolu, jako podopiecz- 
ny niby to, a naprawde zakładnik w mocy cesarza Maurycjusza, przy czym do czasu, jak miał lat 10-12, nauka historyczna posiada o nim sporo informacji, aż nagle wszelkie informacje o nim „mi $1 \mathrm{k} n$ ą”, z czego większość zajmujących się ową epoka historyków wyciaga wniosek, że u marł około roku $590^{5}$... Czyli innymi słowy: nauka historyczna skazała go na śmierć w latach chłopięcych, ale (i to jest początek mojej ostatniej powieści) on pragnie żyć dłużej jeszcze, a więc czego nie chce albo nie może zrobić nauka historyczna, podejmuje się zrobić historyczne też, ale powieściopisarstwo na odmianę - w osobie mojej... Otóż na 651 stronach toczy się dialog wyłącznie między mna a Atanagildem, - na temat, jak mianowicie jego życie ma być przedłużone, $z$ tym, że jego wymagania i pragnienia raz po raz wchodza w stan konfliktu z moimi czy to możliwościami, czy zamierzeniami... Powieść tę dostarczyłem PAX'owi, a więc Lichniak (tym razem „Z urzędu już”, a nie „amatorsko”) przeczytał maszynopis (Sadkowski - nie!) i choć stawia sprawę tak, że mojej powieści PAX nie odrzuci, najjednoznaczniej jemu samemu ta powieść musi podobać się mniej jeszcze nawet niż Sekret trzeciego Izajasza... Jest wysoce prawdopodobne, że surowa ocena przez Lichniaka powieści o Atanagildzie ${ }^{6}$ jest całkowicie zgodna z rzeczywistością, co, oczywiście, może mnie bardzo martwić, nie muszę jednak chyba się tego aż wstydzić, gdyż jeśli na starość (a mam przecież 74 lata!) sprawność zawodowa opuszcza n a t u r al ny m b i e g i e m r ze c zy człow ie c zy ch ślusarza czy szybkobiegacza, czy wyborowego strzelca, to tym samym może (ba, musi nawet) opuszczać pisarza, szczególnie gdy rzeczony pisarz ma za sobą ponad 50 lat pracy i blisko 30 owoców pracy w postaci książek... $Z$ drugiej jednak strony, tworzy się „nieubłagany” wręcz problem: czy w ogóle warto kontynuować pracę, skoro owoce jej c or a z gorsze? Czy nie byłoby lepiej (czy inaczej jeszcze stawiając sprawę: g o d ni j), jeżeliby się definitywnie „zamknęło warsztat"7? Przyjemne by to, oczywiście, nie było, ani też łatwo, choćby w myśl zasady „VIVERE NON EST NECESSE, NAVIGARE NECESSE EST"8, ale mogłoby być konieczne, albo co najmniej już właśnie g o d n e...

Ale zanimbym się naprawdę zdecydował „zamknąc warsztat”, niezbędna by dla mnie była, P a ń s ka, Drogi Panie Jacku, opinia o powieści o Atanagildzie... Z myślą tą noszę się właśnie od 4-5 miesięcy, ale nadać tej myśli formę jawnej i jasnej prośby do Pana nie miałem odwagi - odważam się dopiero teraz, a to po otrzymaniu od Pana pocztówki z miłymi życzeniami wielkanocnymi.

Nie chodzi mi, rzecz jasna, o komplementy ani też w ogóle o „pocieszanie”, ale o pomoc Pańska w trudnym - choć koniecznym - akcie „spojrzenia prawdzie w oczy"... Czy miałby więc Pan i czas, i chęć, i możliwość przeczytania (b a r dzo uważnego i bardzo też krytycznego przeczytania!) powieści o Atanagildzie w maszynopisie? Co prawda, tak jak Darów z Kordoby, nie mogę Panu przesłać maszynopisu poczta, ale może po jakimś czasie zakaz nadawania tego rodzaju przesyłek zostanie cofnięty albo będzie Pan kiedyś w Warszawie, przyjdzie do mnie i weźmie ten maszynopis?

Ogromnie byłbym Panu wdzięczny!

Pozdrawiam Pana najserdeczniej

Teodor Parnicki ${ }^{9}$

List na czterech bardzo cienkich kartkach, zapisanych obustronnie czarnym kolorem. W górnym rogu każdej stronicy pojawia się arabska numeracja (1-7). 
$1 \quad$ Pokłosiem tego jest T. Parni c ki e g o Kryzys i szanse powieści historycznej („Życie i Myśl” 1976, nr 4).

2 T. Parni k i, Dary z Kordoby. Powieść na tle przełomu lat 1018 i 1019. Poznań 1981.

$3 \quad \mathrm{Z}$ powodu wprowadzenia w Polsce stanu wojennego.

4 T. Parni cki, Sekret trzeciego Izajasza. Warszawa 1984.

5 Powiązania dynastyczne Franków i Wizygotów są bardzo skomplikowane. Syg berert I (535/536575), król Austrazji (część Królestwa Franków) był mężem Brunhildy (545/550-613). Ich córka, Ingunda (zm. 585) była żoną św. Hermenegilda (ok. 564-585/586) - księcia wizygockiego, który przeszedł $\mathrm{z}$ arianizmu na katolicyzm, męczennika i patrona konwertytów. Ich z kolei synem był Atanagild (zm. 590?) bohater Rozdwojonego w sobie. Atanagild przebywał na dworze Maury cjusza (539-602), cesarza bizantyjskiego.

6 Mowa tu o Rozdwojonym w sobie T. Parnickieg o (Warszawa 1983).

7 Metafora warsztatu często pojawia się w pisarstwie Parnickiego, a także w jego wypowiedziach nieliterackich. Twórca nie uważa się za artystę ani też za rzemieślnika. Jest rzemieślnikiem artystycznym, kimś na kształt płatnerza, który delikatnie przekuwa w swoim warsztacie historię w literaturę. Zob. P a rn i c ki, Historia w literature przekuwana, s. 33-39.

8 Sentencję Plutarcha (Żywoty sławnych mężów. 〈Z żywotów równoległych〉. Przekł., komentarz M. Brożek. Wyd. 1, dodr. Wrocław 1997, s. 218) dotyczącą Pompejusza można przetłumaczyć tak: „Życie nie jest konieczne, żeglowanie jest konieczne”. Motto to stanowi niejako myśl przewodnią całej twórczości Parnickiego. Żeglowanie może być tu rozumiane jako metafora pisania, które staje się konieczne do życia, a czasem i od niego ważniejsze.

9 Informacja o tym liście pojawia się w Dziennikach z lat osiemdziesiatych Pa r n i ck i e go pod data 18 IV: „Wysłałem do Jacka Łukasiewicza obszerny bardzo list (napisany 17/IV), zawierajacy m.in. sugestię (a właściwie prośbę), ażeby on - gdy wytworzy się ku temu sposobność - zapoznał się w maszynopisie z moją powieścią o Atanagildzie” (s. 249).

1 maja 1982

\section{Drogi Panie Jacku!}

Odpowiedź Pańska na mój list z 17 kwietnia dotarła do mnie nadspodziewanie szybko, bo oto już w dniu wczorajszym ${ }^{1}$. Ogromnie się cieszę $z$ Pańskiej gotowości zapoznania się $\mathrm{w}$ maszynopisie $\mathrm{z}$ moją powieścią o Atanagildzie (oraz ewentualnie z Sekretem trzeciego Izajasza także), a nawet bardziej jeszcze - z perspektywy odwiedzin Pańskich u mnie, a to już w maju². Bardzo mnie, zreszta, wzruszył cały w sensie treści - list Pański i jego - że się i tak też wyrażę - ton.

Dorzuce przy tym (choć na razie skrótowo tylko, szczegóły odkładając do osobistego spotkania) że problem kontynuowania przeze mnie i dalej jeszcze pracy literackiej znalazł się pod znakiem zapytania z przyczyn także i zupełnie innych niż te, o jakich napomykałem w swym liście do Pana z 17/IV. Oto p od ob no (piszę „podobno”, gdyż sam jeszcze tego nie czuję) jestem poważnie bardzo (zdaniem lary ngo log ó w i w świetle pewnych badań laboratoryjnych i rentgenologicznych), bardzo poważnie chory

Pani Teresy ręce czule całuję - Pana ściskam serdecznie - Ela łączy dla obojga Państwa moc pozdrowień!

Teodor P.

List na jednej karcie, złożonej w kwadrat, zapisany na s. 1 i 3 niebieskim atramentem.

1 W dzienniku Parni cki (ibidem, s. 252) notuje pod datą 30 IV 1982: „Odpowiedź nadeszła (bar- 
dzo miła i zapowiadająca odwiedziny u mnie w maju) od Jacka Łukasiewicza na mój list z 17 kwi et nia”, a pod data 2 V 1982: „Wysłałem drugi list do Jacka Łukasiewicza” (ibidem).

O dalszym ciągu dowiadujemy się z dzienników (ibidem, s. 262, z 16 VI 1982): „Dzwonił z Wrocławia Jacek Łukasiewicz”, a przede wszystkim: „Był u mnie Jacek Łukasiewicz - przyjechał z Wrocławia - nie widzieliśmy się bardzo dawno. Dałem mu: 1) do przeczytania i do ocenienia mój własny maszynopis powieści o Atanagildzie, 2) Dary z Kordoby, 3) książkę Meysztowicza Trzecia postać Marianny dla Magdy Lukasówny" (ibidem, s. 262-263, z 17 VI 1982). Łukasiewicz wysłał Parnickiemu pocztą omówienie Rozdwojonego w sobie (30 VII 1982), a następnie rozmawiali o tym przez telefon (31 VII 1982) - zob. ibidem, s. 277-278.

3 Chodzi o raka gardła, $\mathrm{z}$ którym Parnicki zmagał się od 1982 roku.

\section{4}

[grudzień 1982]

Szczę śliw e go Nowego Roku 1983 życzą najserdeczniej Teodor i Eleonora Parniccy

Świąteczna, składana kartka pocztowa ze zdjęciem zimowego lasu. Życzenia zapisane zostały w środku granatowym atramentem. Słowa „Szczęśliwego Nowego Roku” są częścią nadruku. Nadruk stanowią życzenia w pięciu językach.

\section{5}

[marzec 1983]

Za miłą bardzo pamięć o dniu, w którym ukończył 75 lat, Teodor Parnicki ${ }^{1}$ dziękuje najserdeczniej Drogim Państwu Teresie i Jackowi Łukasiewiczom.

Słowa na jednej karcie, zapisanej fioletowym flamastrem.

1 Kolorem czerwonym.

\section{6}

30 grudnia 1983

Najszczęśliwszego roku 1984 życzą Drogim Państwu najserdeczniej Teodor i Eleonora Parniccy

Kartka świąteczna ze zdjęciem stroika. Na s. 2 słowa skreślone przez Parnickiego zielonym pisakiem. Kartka jest zaadresowana na wrocławski adres Jacka Łukasiewicza.

\section{7}

[grudzień 1984]

Szczęśliwego Nowego 1985 Roku życzą Drogim Państwu Teresie i Jackowi Łukasiewiczom Teodor i Eleonora Parniccy

Świąteczna, składana kartka pocztowa ze zdjęciem zimowego lasu (identyczna jak z grudnia 1982). Wewnątrz słowa Parnickiego napisane czarnym atramentem. Życzenia „Szczęśliwego Nowego Roku” są częścią nadruku. 
[grudzień 1985]

Drogim Państwu Teresie i Jackowi Łukasiewiczom wraz z Synami najszczęśliwszego roku 1986 życzą najserdeczniej Eleonora i Teodor Parniccy.

Składana kartka pocztowa z obrazem przedstawiającym świętujące indyjskie kobiety. Wewnątrz słowa zapisane przez Parnickiego zielonym flamastrem.

[grudzień 1986]

Pomyślnego roku 1987 życzą najserdeczniej Teodor i Eleonora Parniccy.

Kartka pocztowa ze zdjęciem bukietu kwiatów. Na s. 2 życzenia zapisane przez Parnickiego zielonym flamastrem. Kartka została wysłana na wrocławski adres Łukasiewicza, lecz data na stemplu jest nieczytelna.

60

24 lutego 1987

Drogi Panie Jacku!

Bardzo zły stan mojego wzroku (lewe oko zupełnie „zgasło”, a prawe wprawdzie jeszcze funkcjonuje, lecz rzecz to niewiadoma, ile czasu będzie funkcjonowało!) ogromnie mi utrudnia pisanie wszelkie, a co jest rzeczą może gorsza jeszcze, prawie zupełnie już uniemożliwia czytanie. Więc będzie, oczywiście, wyglądać na paradoks, że zwracam się do Pana z prośbą natury właśnie „książkowej”, jednakże wchodzi w grę zrobienie prezentów: zarówno żonie własnej, jak komuś w Meksyku. Właśnie o Meksyk chodzi mi: wrocławskie Ossolineum wydało Łe pk ow sk i e g o Historię Meksyku ${ }^{1}$ - jest dla mnie rzeczą niemożliwą dostać w Warszawie to, - czy mógłby [Pan] dostać (czyli kupić) dla mnie dwa egzemplarze we Wrocławiu i posłać mi to pocztą? Ogromnie byłbym wdzięczny.

(Przepraszam, dopiero teraz zauważyłem, że drugą stronę listu do Pana piszę na stronie, zadrukowanej już - na stronie chyba jakiegoś fotostatu ${ }^{2} \mathrm{z}$ jakiegoś również dzieła historycznego ${ }^{3}$, dawno mi niepotrzebnego - spodziewam się, że jednak będzie to, co piszę także i na takiej stronie, okaże się dla Pana czytelne. Ma właśnie Pan próbkę niedogodności, powodowanych przez stan mojego wzroku byłoby znacznie lepiej, jeżelibym do Pana zatelefonował, ale od dwóch tygodni telefon mój nie funkcjonuje - nie tylko, zresztą mój, gdyż sporo telefonów w okolicy bliższej i dalszej - jest to, niestety, sytuacja, która trwać może cały miesiąc! ${ }^{4}$

Natychmiast gdy mi pan napisze, że książki kupić może (lub już kupił) i ile ma zapłacić (lub już zapłacił), przekażę Panu pocztą równowartość (cena książek plus opłata pocztowa). Przepraszam bardzo za kłopot. Z góry dziękuję Panu najserdeczniej. Jest to rzecz bardzo dziwna: właściwie piszę „mózgiem” tylko, a nie „oczyma” - słów, przed chwila przez siebie napisanych, prawie zupełnie nie jestem w stanie odczytać. 
Mam w domu inne jeszcze kłopoty: moja żona miała operację (ogromny - a niewiadomego pochodzenia - ropień pod lewa pachą; zachodziła przy tym obawa, że w grę wchodzi nowotwór - na szczęście, tego rodzaju domysły lekarzy onkologów okazały się bezpodstawne).

Raz jeszcze gorąco Panu dziękuję. Całuję ręce Pani Teresy - Pana ściskam bardzo serdecznie - Teodor P. ${ }^{5}$

List na dwóch różnych kartach, zapisanych obustronnie niebieskim atramentem. W prawym górnym rogu każdej stronicy pojawia się numeracja arabska (1-4). W lewym górnym rogu s. 1 znajduje się naklejka $\mathrm{z}$ adresem Parnickiego: „Teodor Parnicki / ul. Zimorowicza 2 m. 10 / 02-062 Warszawa).

1 T. Łepkows ki, Historia Meksyku. Wrocław 1986.

2 Fotostat - odbitka, kopia fotograficzna, kserokopia.

3 Faktycznie - s. 2 pierwszej karty tego listu jest już zadrukowana. Artykuł ten to najpewniej B. Kü rb is Dagome iudex-studium krytyczne (w zb.: Poczatki państwa polskiego. Ksiega tysiaclecia. Red. K. Tymieniecki. T. 1. Poznań 1962).

4 Zob. list T. Parnickiego do B. Kledzika z Wydawnictwa Poznańskiego (list 16, z 2 III 1987): „Od 13 lutego telefon mój nie funkcjonuje (nie tylko, zresztą, mój, gdyż liczne telefony w okolicy bliższej i dalszej). Jak głoszą różne wiadomości (plotki sąsiedzkie oraz wypowiedzi - niechętne, zresztą, bardzo - Biura Napraw), stan taki trwać może mi e s i ą c c ały, a ostatnio doszły do mnie pogłoski, że się zepsuł podziemny kabel, którego nie ma podobno czym zastapić, chyba iż się sprowadziłoby nowy z zagranicy?!” (cyt. z: „We mnie trzeba być”. Listy Teodora Parnickiego ze zbiorów Biblioteki Raczyńskich w Poznaniu. Oprac. T. M a r k i e w k a. „Pamiętnik Literacki” 2011, z. 3, s. 213). O problemie z telefonem wspomina Parnicki także w Dziennikach z lat osiemdziesiatych.

$5 \quad$ Wysłanie listu Pa rn i cki (Dziennik z lat osiemdziesiatych, s. 417) sygnalizuje pod datą 24 II 1987.

61

Wtorek, 10 marca 1987

Drogi Panie Jacku!

Wczoraj doręczono mi paczkę od Pana zawierająca dwa egzemplarze Historii Meksyku Łepkowskiego․ Dziękuję Panu najgoręcej za łaskawe i szybkie spełnienie tej mojej prośby. Wygląda na to, że była to przesyłka „w a r t o ś c i o w a”, a nie zwyczajna „polecona”, gdyż przyniósł ją specjalny goniec z poczty, a nie zwyczajna nasza rejonowa doręczycielka.

Tak czy owak, paczka s z c z ęśli i i e doszła (dużo paczek z książkami właśnie nie dochodzi do adresata!).

Zgodnie z życzeniem Pańskim, wyrażonym w liście, który nadszedł w tym samym dniu co książki, n i e przekazuję pieniędzy, ale czekam - z nimi - a i w ogóle czekam z niecierpliwością na zapowiedziane łaskawie odwiedziny Pańskie. Niestety, telefon mój jest dalej nieczynny; mówi się o jakimś szczególnie trudnym do naprawienia pęknięciu kabla (są nawet pogłoski, że kabel taki trzeba byłoby sprowadzać z zagranicy!), więc przykra sytuacja ta trwać może długo - może miesiące jeszcze, a może nawet (takie są sąsiedzkie plotki) dłużej. - Jak więc zorganizować Pańskie u nas odwiedziny. Najpierw, rzecz jasna, niech łaskawie sprawdzi Pan po przyjeździe do Warszawy - może się okaże, że mój telefon już działa. Gdyby i dalej jeszcze nie działał (najgorsze jest to, że daje on sygnał „normalny”, co w błąd wprowadza ludzi chcących ze mną porozumieć się). 
Wychodzę bardzo mało $z$ domu, więc wchodzi w grę ryzyko min i malne, że przychodząc do nas, nikogo nie będzie w domu. Ale pewne ryzyko jest: parę razy dziennie wychodzę z żoną i psem do parku (zwykle koło 6-tej po południu i późnym wieczorem, ale niekiedy i w południe). Bywa też, że wyjeżdżam do lekarza (jak dotąd, nie nazbyt często) albo wychodzę z żoną na p o b li s k i e ulice na zakupy, na pocztę etc.

Ale w drzwiach wejściowych naszego mieszkania jest otwór z napisem „Listy”: gdyby na dzwonek (lub na pukanie, gdyż często u nas psuje się światło, a więc i dzwonek przestaje działać) nie otworzono Panu i miałby Pan odejść, to proszę do tego właśnie otworu $z$ napisem "Listy” wrzucić karteczkę $z$ wiadomością, że następny raz przyjdzie Pan wtedy to a wtedy (dzień - oraz godzina, w przybliżeniu przynajmniej).

Jeszcze raz najserdeczniej Panu dziękuję i równie serdecznie Pana ściskam - Czekam na Pana!

Teodor Parnicki

List na dwóch kartach, zapisanych obustronnie niebieskim atramentem. W górnym rogu każdej stronicy pojawia się numeracja arabska (1-4).

1 Paczka - według notatki w dzienniku pod data 10 III 1987 (wysłanie listu przez pisarza) - przyjść miała 9 III. Zob. Parnicki, Dzienniki z lat osiemdziesiatych, s. 418.

\section{Drogi Panie Jacku!}

Od przedwczorajszego (środa) południa telefon mój już znów nareszcie funkcjonuje (przypominam numer: 25-48-35). Rzecz jasna, chciałem o tym Pana natychmiast zawiadomić, wydało mi się jednak, że będzie lepiej, jeżeli zawiadomię nie listownie, ale telefoniczne. Ale przez półtora dnia nikt nie odzywał się u Pana w domu. Więc może ja mam błędnie zapisany numer Pańskiego telefonu (55-82-48). Albo przez cały ten czas nie było nikogo u Pana w domu? Albo może na odmianę zepsuł się Pański telefon? Nie wchodzi w rachubę moja niemożliwość połączenia się z Wrocławiem, gdyż właśnie przedwczoraj już telefonowałem do Wrocławia do znanego może i Panu też Tadeusza Banasia, którego znam od lat już prawie sześćdziesięciu. Uzyskałem bez trudu połączenie telefoniczne i z tymże Tadeuszem Banasiem rozmawiałem.

Czekam na Pański przyjazd do Warszawy. Na razie pozdrawiam Pana najserdeczniej!

Teodor Parnicki ${ }^{1}$

List na jednej karcie, zapisanej obustronnie niebieskim atramentem.

$1 \quad$ Wysłanie listu sygnalizuje Pa rn i cki (Dzienniki z lat osiemdziesiatych, s. 419) w notatce pod data 20 III 1987. 
[marzec 1988]

Teodor Parnicki dziękuje najserdeczniej za łaskawą i miłą bardzo pamięć o dniu, w którym ukończył 80 lat $^{1}$

Kartka pocztowa ze zdjęciem bukietu kwiatów. Na odwrocie słowa zapisane przez Parnickiego zielonym kolorem. Kartka wysłana na wrocławski adres Łukasiewicza (data na stemplu nieczytelna).

1 Telegram od Łukasiewiczów z życzeniami urodzinowymi zapisuje Parnicki (Dzienniki z lat osiemdziesiatych, s. 439) w notatce pod 5 III 1987, przy dacie swoich urodzin.

\section{4}

Składaja - łączac serdeczne pozdrowienia Teodor i Eleonora Parniccy ${ }^{1}$

Składana kartka noworoczna. Na s. 1 widnieje napis: „Najlepsze życzenia noworoczne”. Wewnątrz, skreślone zielonym flamastrem, słowa Parnickiego.

$1 \quad$ Kartka nie nosi daty, a że trudno ją ustalić, dołączamy jednostkę na końcu zbioru.

\section{Listy Eleonory Parnickiej do Jacka Łukasiewicza}

\section{Drogi Panie Jacku!}

Przepraszam, że dopiero teraz się odzywam na tak serdeczny i pełen współczucia dla mnie list Pana. Naprawdę nie byłam w stanie zabrać się do pisania listów, a i teraz jest mi szalenie trudno pisać o tych sprawach.

Wie Pan, jak bardzo z Teodorem byliśmy sobie bliscy, a ostatnio w ogóle nie rozstawialiśmy się ani na chwilę. Tym okropniejsze dla mnie jest to tak nagłe i niespodziewane rozstanie.

Chciałam Panu powiedzieć, że Opowieść o trzech Metysach ${ }^{1}$ została przyjęta do druku przez Wyd[awnictwo] Poznańskie na niewiele dni przez śmiercią Teodora, z czego cieszył się ogromnie (jak Pan wie, zawsze żywił obawy, czy jego dzieło będzie zaakceptowane...). Pozostawił po Sobie w rękopisie, który w tej chwili przepisuję na maszynie, tekst składający się z 3-ch części i Epilogu, którego nie dokończył; dosłownie na biurku pozostało niedokończone zdanie... Ma to być trylogia, której ogólnego tytułu nie nadał, poszczególne części to:

Czy remis?

Porażka, ale czyja?

Abdykacja

i Epilog pt. Następca 
Wszystko to zostało na półkach, opatrzone tytułami i instrukcjami, co jest co, jak należy przepisywać etc. Naprawdę zadziwiające, gdy się weźmie pod uwagę, że pisał po omacku, bo już prawie nie widział.

Jeszcze raz gorąco Państwu obojgu dziękuję za słowa współczucia i przyjaźni

E. Parnicka

List na papeterii, napisany na maszynie. Nagłówek i podpis - niebieskim atramentem.

1 Opowieść o trzech Metysach ukazała się ostatecznie dopiero 6 lat po śmierci Parnickiego, w 1994 roku i nakładem warszawskiego wydawnictwa „Noir sur Blanc” (t. 1: Raczej jednak oni, t. 2: Raczej ja). Zob. list 5 od E. Parnicki ej. Powieść ta jest zadedykowana „Jackowi i Teresie Łukasiewiczom".

2

23.12.1989

Najlepsze życzenia Świąteczne i Noworoczne wraz z pozdrowieniami przesyła Ela Parnicka Święta 1989 r.

Świąteczna kartka pocztowa ze zdjęciem stroika. Na odwrocie niebieskim długopisem - słowa skreślone przez Parnicka. Kartka z adresem wrocławskim Łukasiewicza, data ze stempla pocztowego.

20 marca 1990

Drogi Panie Jacku!

Serdecznie dziękuję za przesłanie mi „Odry” z Pana artykułem ${ }^{1}$. Artykuł przeczytałam wcześniej, bo ktoś ze znajomych mi zasygnalizował, że w tym numerze „Odry” jest artykuł Pana, ale z przyjemnością zachowam numer od Pana w moim archiwum. Artykuł wzruszył mnie bardzo, szczególnie ustępy bardzo osobiste, które w nim się znalazły. Wciąż tak trudno mi się przyzwyczaić do myśli, że jestem sama już na zawsze i tego najbliższego mi Przyjaciela nie będzie przy mnie.

Skończyłam przepisywanie tego, co pozostawił Teodor. Wyszło to ogromne dzieło: 3 tomy, każdy w maszynopisie ma przeszło 300 stron, a Epilog (nie dokończony) nawet więcej.

Jak Pan wie, w tej chwili sytuacja wydawnicza jest zupełnie beznadziejna, nie wiem więc, kiedy i czy w ogóle ujrzy to światło dzienne. Na razie jest przepisane ${ }^{2}$.

Wracając do magistranta, p. Bogusława Szpytmy ${ }^{3}$, to mam do Pana prośbę i z góry przepraszam za kłopot. Otóż wypożyczyłam, może lekkomyślnie, jedyny egzemplarz posłowia p. Małgorzaty Czermińskiej do wydania Aecjusza w języku niemieckim ${ }^{4}$ (posłowie po polsku) i p. Szpytma obiecał mi je odesłać, ale do tej pory tego nie uczynił. Zostawił mi wprawdzie swój adres, ale uprzedził, że się właśnie stamtąd przeprowadza (boję się, że moje pisanie do niego na adres, który już jest nieaktualny, mijałoby się z celem). Proszę więc Pana bardzo przypomnieć mu przy 
okazji, że obiecał ten jedyny egzemplarz mi odesłać. Dziękuję z góry i jeszcze raz przepraszam za kłopot.

Ela $\}^{5}$

\{Serdecznie pozdrawiam Pana i p. Terese

List na jednej karcie, napisany na maszynie. Nagłówek i podpis - niebieskim atramentem.

1 J. Łu k a s i e w i c z, Gwiazda Parnickiego. „Odra” 1989, nr 12. W szkicu tym autor cytuje fragmenty prezentowanego tu zbioru listów, wraz z komentarzem.

2 Powieść ta ukazała się dopiero w 2003 roku nakładem wydawnictwa „Noir sur Blanc”. Zob. T. P a rni cki, Ostatnia powieść. T. 1-2. Warszawa 2003.

3 Najprawdopodobniej chodzi o Bogusława Sz py t m ę (ur. 1963) - absolwenta polonistyki Uniwersytetu Wrocławskiego, od 2006 roku burmistrza Kłodzka.

4 Wspomniana edycja to przypuszczalnie Aetius, der letzte Roemer. Roman (Frankfurt am Main 1989).

5 Tekst zapisany odręcznie, na marginesie s. 2.

4

[grudzień 1990]

Dziękując za miłe życzenia, ze swej strony ślę Państwu najlepsze życzenia na Rok $1991 y$

E. Parnicka

Składana kartka noworoczna. Na s. 1 widnieje nadruk z życzeniami. Wewnątrz, niebieskim długopisem, słowa skreślone przez Parnicka.

5

styczeń $1995 \mathrm{r}$.

Drodzy Państwo!

Nareszcie ukazała się Opowieść o trzech Metysach! Pozwalam sobie przesłać egzemplarz Państwu zadedykowany przez Autora.

Ukłony i pozdrowienia

E. Parnicka

Składana kartka pocztowa z rysunkiem kwiatów w donicy, zapisana wewnątrz niebieskim atramentem.

\section{Dedykacje autorskie na książkach Teodora Parnickiego}

Nowa baśń. Cz. 2: Czas siania i czas zbierania

Drogiemu Panu Jackowi Łukasiewiczowi z gorącym podziękowaniem za wierną uwagę dla mojej pracy pisarskiej, - oraz z równie gorąca radością, iżeśmy się nareszcie spotkali osobiście

Teodor Parnicki

Wrocław, 14/I [19]64 
Twarz księżyca. Cz. 3

Warszawa, 12/XI 1967

Drogiemu Panu Jackowi Łukasiewiczowi z wyrazami przyjaźni i z goracym podziękowaniem za wierną uwagę, poświęcaną moim książkom

Teodor Parnicki

Nowa baśń. Cz. 5: Wylęgarnie dziwów

8 lipca 1968

Drogi Panie Jacku!

Dłoń Pańską ściskam gorąco

Teodor Parnicki

„Zabij Kleopatrę"

Dłoń Pańską ściskam najgoręcej, Drogi Panie Jacku!

Teodor Parnicki

Warszawa, listopad 1968

Inne życie Kleopatry

Drogich Państwa Teresę i Jacka Łukasiewiczów wraz z Synami pozdrawia najserdeczniej Teodor Parnicki.

Warszawa, czerwiec 1969

Muza dalekich podróży

Warszawa, listopad $1970^{1}$

Drogiego Pana Jacka Łukasiewicza pozdrawia najserdeczniej

Teodor Parnicki ${ }^{2}$

$1 \quad$ Kolorem czerwonym.

2 Kolorem czerwonym.

Tożsamość

Drogim Państwu Teresie i Jackowi Łukasiewiczom wraz z Synami najszczęśliwszego roku 1971 życzy wraz z Elą najserdeczniej

Teodor Parnicki ${ }^{1}$

1 Kolorem czerwonym.

Nowa baśń. Cz. 6: Palec zagrożenia

Drogiego Pana Jacka Łukasiewicza pozdrawia najserdeczniej

Teodor Parnicki

Warszawa, Lipiec 1970

Staliśmy jak dwa sny

Drogiego Pana Jacka Łukasiewicza pozdrawia najserdeczniej

Teodor Parnicki

Kwiecien $1973^{1}$

$1 \quad$ Kolorem czerwonym. 


\title{
Przeobrażenie
}

\section{Drogiego Pana Jacka Łukasiewicza pozdrawia najserdeczniej Teodor Parnicki Wrzesień $1973^{1}$}

$1 \quad$ Kolorem czerwonym.

\section{Rodowód literacki}

Te o d or Parnicki - T. P. wraz z żoną swoją, Elą, najserdeczniejsze Życzenia na rok $1975^{1}$ śle Drogim Państwu Teresie i Jackowi Łukasiewiczom wraz z Synami

Nazwisko autora stanowi nadruk na stronie tytułowej. Parnicki podkreślił je i dopisał swoje inicjały.

1 Kolorem czerwonym.

\section{Dary z Kordoby}

Drogiemu Panu Jackowi Łukasiewiczowi oraz Jego Najbliższym n aj s z c z ę ś 1 i ws ze go roku $1982^{1}$ życzy naj serdeczni ej wraz z żoną swoją, Elą Autor

Na następnej stronicy, powyżej nadrukowanego nazwiska autora - jeszcze raz podpis.

1 Kolorem czerwonym.

\author{
Abstract
}

\section{"NONE OF THE CRITICS TO THE EXTENT AS YOU HAS PIERCED INTO THE "CRUCIAL SENSE" "TEODOR AND ELEONORA PARNICCY'S LETTERS TO JACEK LUKASIEWICZ \\ Edited by \\ PIOTR GORLIŃSKI-KUCIK University of Silesia, Katowice}

Between 1959-1995 Teodor Parnicki and his second wife Eleonora exchanged over 60 letters and postcards with Jacek Łukasiewicz, a literary scholar, poet, lecturer, and critic. The large collection preserved in the addressee's archive offers, for a Parnicki researcher, numerous valuable pieces of information about the writer's life, his creative process, and a number of interpretative tropes.

The first letters sent by Parnicki from Mexico, where he stayed as an emigrant, refer mainly to Łukasiewicz's critical sketches on Parnicki's novels. The following letters speak about the current matters, frequent requests connected with the Parnicki's removal to Poland, as well as the writer's health matters.

Publication of the collection, crucial due to both correspondents' contribution to culture, is included into a renaissance of interest in Parnicki's writing and to processing his so far unpublished materials. 